\title{
Loss of M1 Receptor Dependent Cholinergic Excitation Contributes to mPFC Deactivation in Neuropathic Pain
}

\author{
Daniel Radzicki, ${ }^{1}$ Sarah L. Pollema-Mays, ${ }^{1}$-Antonio Sanz-Clemente, ${ }^{2}$ and Marco Martina ${ }^{1}$ \\ ${ }^{1}$ Department of Physiology and ${ }^{2}$ Department of Pharmacology, Northwestern University Feinberg School of Medicine, Chicago, Illinois 60611
}

In chronic pain, the medial prefrontal cortex (mPFC) is deactivated and $\mathrm{mPFC}$-dependent tasks such as attention and working memory are impaired. We investigated the mechanisms of mPFC deactivation in the rat spared nerve injury (SNI) model of neuropathic pain. Patch-clamp recordings in acute slices showed that, 1 week after the nerve injury, cholinergic modulation of layer 5 (L5) pyramidal neurons was severely impaired. In cells from sham-operated animals, focal application of acetylcholine induced a left shift of the input/output curve and persistent firing. Both of these effects were almost completely abolished in cells from SNI-operated rats. The cause of this impairment was an $\sim 60 \%$ reduction of an M1-coupled, pirenzepine-sensitive depolarizing current, which appeared to be, at least in part, the consequence of M1 receptor internalization. Although no changes were detected in total M1 protein or transcript, both the fraction of the M1 receptor in the synaptic plasma membrane and the biotinylated M1 protein associated with the total plasma membrane were decreased in L5 mPFC of SNI rats. The loss of excitatory cholinergic modulation may play a critical role in mPFC deactivation in neuropathic pain and underlie the mPFC-specific cognitive deficits that are comorbid with neuropathic pain.

Key words: internalization; muscarinic; pyramidal cell; SNI; working memory

Significance Statement

The medial prefrontal cortex (mPFC) undergoes major reorganization in chronic pain. Deactivation of mPFC output is causally correlated with both the cognitive and the sensory component of neuropathic pain. Here, we show that cholinergic excitation of commissural layer $5 \mathrm{mPFC}$ pyramidal neurons is abolished in neuropathic pain rats due to a severe reduction of a muscarinic depolarizing current and M1 receptor internalization. Therefore, in neuropathic pain rats, the acetylcholine (ACh)-dependent increase in neuronal excitability is reduced dramatically and the ACh-induced persisting firing, which is critical for working memory, is abolished. We propose that the blunted cholinergic excitability contributes to the functional mPFC deactivation that is causal for the pain phenotype and represents a cellular mechanism for the attention and memory impairments comorbid with chronic pain.

\section{Introduction}

Working memory and attention impairments accompany chronic pain in patients (Moriarty et al., 2011; Baker et al., 2016) and in animals (Pais-Vieira et al., 2009a; Ren et al., 2011), and animal models of persistent pain are characterized by functional deactivation of the medial prefrontal cortex (mPFC) (Metz et al., 2009; Neugebauer et al., 2009; Pais-Vieira et al., 2009b; Ji et al., 2010; Lee et al., 2015; Zhang et al., 2015; Kelly et al., 2016), although the mechanisms of the

\footnotetext{
Received May 12, 2016; revised Dec. 1, 2016; accepted Jan. 5, 2017.

Author contributions: M.M. designed research; D.R., S.L.P.-M., and A.S.-C. performed research; D.R., S.L.P.-M., A.S.-C., and M.M. analyzed data; D.R., A.S.-C., and M.M. wrote the paper.

This work was supported by the National Institutes of Health (Grants NS064091, DE022746, and AG041225).

The authors declare no competing financial interests.

Correspondence should be addressed to Marco Martina, M.D., Ph.D., Department of Physiology,

Northwestern University Feinberg School of Medicine, 303 E. Chicago Avenue, Chicago, IL 60611. E-mail: m-martina@northwestern.edu.

DOI:10.1523/JNEUROSCI.1553-16.2017

Copyright $\odot 2017$ the authors $\quad 0270-6474 / 17 / 372292-13 \$ 15.00 / 0$
}

deactivation remain largely unexplored. The mPFC receives and integrates synaptic inputs from sensory areas (Vertes et al., 2007) and limbic regions (Vertes, 2006), which impart emotional salience onto peripheral stimuli, and modulatory afferents from regions such as the nucleus basalis of the basal forebrain (Mesulam et al., 1983), which provide cholinergic input important for cue detection and "allocation of processing resources" (Sarter and Bruno, 1997). The more ventral subregions of the mPFC, the prelimbic (PL) and infralimbic (IL) cortices, receive hippocampal (Jay et al., 1989; Parent et al., 2010), amygdalar, and thalamic glutamatergic inputs (Krettek and Price, 1977; Vertes et al., 2007). Cholinergic afferents can activate excitatory networks in both layer 2/3 (L2/3) (Vidal and Changeux, 1993) and L5 (Guillem et al., 2011) and the disruption of cholinergic signaling in the mPFC has been shown to adversely affect attentional processing and working memory tasks (Granon et al., 1995). Pyramidal neurons in L5, which provide the main output of the $\mathrm{mPFC}$, receive these multiple inputs and create the reciprocal connections thought to underlie working memory (Goldman- 


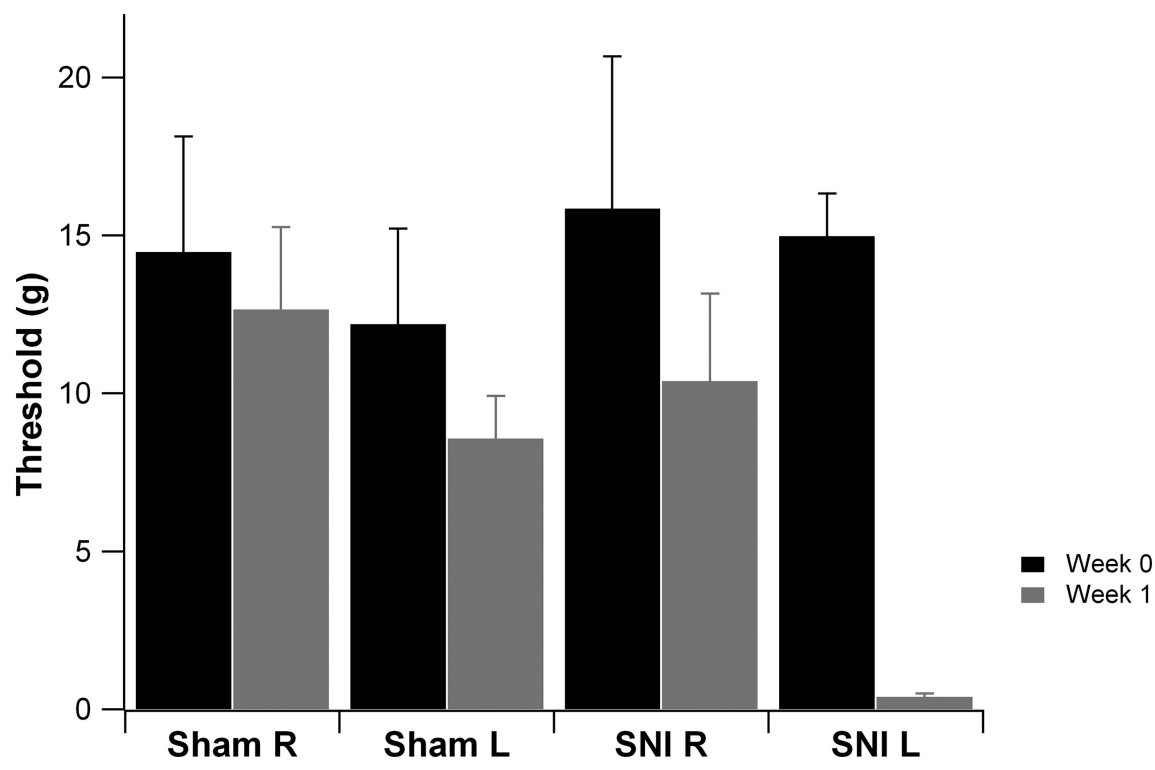

Figure 1. Tactile threshold is markedly reduced in the injured paw of SNI rats 1 week after surgery. Before surgery (week 0 ), there was no significant difference in the tactile threshold of the right and left hindpaws of sham $(14.47 \pm 3.5 \mathrm{~g}$ and $12.2 \pm 3.0 \mathrm{~g}$, respectively, $n=19$ ) or SNI animals (15.8 $\pm 4.8 \mathrm{~g}$ and $14.97 \pm 3.8 \mathrm{~g}$, respectively, $n=14)$. One week after surgery (week 1$)$, tactile thresholds in sham animals were $12.7 \pm 2.6 \mathrm{~g}$ on the right paw contralateral to the surgery site and $8.6 \pm 1.4 \mathrm{~g}$ on the left paw. In SNI animals, no significant change in threshold was detected in the right hindpaw (10.4 $\pm 2.8 \mathrm{~g}$ ), whereas a significant drop was observed in the left hindpaw ipsilateral to the surgery site $(0.4 \pm 0.1 \mathrm{~g}, p=0.002)$.

Rakic, 1995). Cortical cholinergic modulation is related to attention and working memory (Croxson et al., 2011; Hasselmo and Sarter, 2011) and is mediated by both nicotinic and muscarinic receptors (Mansvelder et al., 2006; Arroyo et al., 2014). In the mPFC, activation of postsynaptic M1 receptors modulates pyramidal cell excitability through several mechanisms. It mediates a slow membrane depolarization (Haj-Dahmane and Andrade, 1996; Kurowski et al., 2015) that enhances temporal summation (Carr and Surmeier, 2007) and increases neuronal firing frequency (Satake et al., 2008). M1 activation also facilitates a slow afterdepolarization (sADP) (Haj-Dahmane and Andrade, 1997; 1999; Lei et al., 2014) which promotes persistent firing (McQuiston and Madison, 1999). Acetylcholine (ACh) release in the mPFC correlates with temporally discrete tasks such as successful cue detection (Parikh et al., 2007) and with the persistent activity necessary for spatial working memory (Jung et al., 1998; Romanides et al., 1999). Interestingly, these executive functions, which require cholinergic modulation of the medial prefrontal circuitry, are impaired in different models of chronic pain (Pais-Vieira et al., 2009a; Ji et al., 2010; Ren et al., 2011).

Because of the fundamental role of cholinergic modulation in attention and memory tasks (Klinkenberg and Blokland, 2011; Arnsten and Rubia, 2012), we hypothesized that the increase in neuronal excitability induced by cholinergic modulation is impaired in the pain condition; if so, this may represent both a mechanism for cortical deactivation and a cellular substrate for the mPFC-dependent cognitive impairments. To assess this hypothesis, we used ex vivo slices of rat PL mPFC to compare the effects of cholinergic modulation in control animals and in the spared nerve injury (SNI) model of neuropathic pain 1 week after neuropathic lesion. We focused on L5 pyramidal cells because these cells provide the main output to the nucleus accumbens, the deactivation of which plays a causal role in the neuropathic pain phenotype (Lee et al., 2015). We found that the increased intrinsic excitability of L5 pyramidal neurons induced by M1 receptor activation in sham animals was virtually abolished in SNI animals. Although the total amount of M1 protein was unaf- fected, both the level of M1 protein expressed at cell surface and the fraction associated with the synaptic plasma membrane (SPM) were reduced, suggesting receptor internalization as a mechanism for the disruption of cholinergic modulation in neuropathic pain.

\section{Materials and Methods}

Protocols. All experiments followed protocols approved by the Northwestern University Center for Comparative Medicine.

SNI model. Twenty-one- to 24-d-old male Sprague Dawley rats were anesthetized using gas anesthesia (isoflurane $2-3 \%$ and $30 \% \mathrm{~N}_{2} \mathrm{O}, 70 \%$ $\mathrm{O}_{2}$ ). The left sciatic nerve was exposed at the level of the trifurcation of the peroneal, tibial, and sural branches. Both the peroneal and tibial nerves were tightly ligated at 2 separate points $\sim 3 \mathrm{~mm}$ apart using \#6 sutures (Decosterd and Woolf, 2000). Sterile scissors were used to make cuts within both suture points and the excised $3 \mathrm{~mm}$ nerves were removed; the sural nerve was left intact. The skin was then sutured and treated with antibiotic ointment. Animals were placed under a heating element until they regained consciousness. A second group of animals received a sham surgery. In this case, the nerves were exposed but left untouched.

Behavioral testing. Seven days after SNI/sham surgery, tactile withdrawal responses were measured by mechanically stimulating the left hindpaw (in the area corresponding to sural nerve innervation) using von Frey hairs. Animals were placed in a cage with a wire grid floor within an isolated room and allowed to habituate for a minimum of $20 \mathrm{~min}$. Filaments (Stoelting) of increasing force were applied to the plantar surface of the hindpaw for a maximum of $6 \mathrm{~s}$. Paw withdrawal during application was recorded as a positive response. Fifty percent response thresholds were calculated according to the method of Chapman et al. (1998). SNI surgery induced a robust allodynic response in all animals (Fig. 1).

Patch-clamp recordings in acute slices. Twenty-eight- to 31-d-old male Sprague Dawley rats that had previously undergone either SNI or sham surgery were anesthetized with an intraperitoneal injection of ketamine and xylazine (100 and $20 \mathrm{mg} / \mathrm{kg}$ ). The animals were then perfused with an ice-cold $\mathrm{N}$-methyl-D-glucamine (NMDG) solution containing the following (in mM): $92 \mathrm{NMDG}, 2.5 \mathrm{KCl}, 1.25 \mathrm{NaH}_{2} \mathrm{PO}_{4}, 30 \mathrm{NaH}_{2} \mathrm{CO}_{3}, 20$ HEPES, 25 glucose, 2 thiourea, $5 \mathrm{Na}$ L-ascorbate, 2 Na-pyruvate, 0.5 $\mathrm{CaCl}_{2}$, and $10 \mathrm{MgCl}_{2}, \mathrm{pH} 7.32-7.4$ (titrated with $4 \mathrm{~N} \mathrm{HCl}$ and saturated with $95 \% \mathrm{O}_{2}$ and $5 \% \mathrm{CO}_{2}$ ). The brain was removed from the skull in ice-cold NMDG solution and cut just caudal to bregma. Then, 300- $\mu \mathrm{m}-$ thick coronal slices were cut using a vibro-slicer (Leica VT-1200), stored for $\sim 20 \mathrm{~min}$ at $35^{\circ} \mathrm{C}$, and allowed to recover at room temperature (22$24^{\circ} \mathrm{C}$ ) for at least $30 \mathrm{~min}$ in NMDG solution (saturated with $95 \% \mathrm{O}_{2}$ and $5 \% \mathrm{CO}_{2}$ ). For recordings, slices were transferred to a recording chamber and continuously superfused with ACSF containing the following (in mM): $125 \mathrm{NaCl}, 25 \mathrm{NaHCO}_{3}, 2.5 \mathrm{KCl}, 1.25 \mathrm{NaH}_{2} \mathrm{PO}_{4}, 25$ glucose, 1.2 $\mathrm{CaCl}_{2}$, and $1 \mathrm{MgCl}_{2}$ saturated with $95 \% \mathrm{O}_{2}$ and $5 \% \mathrm{CO}_{2}$. Bath temperature was kept between $30^{\circ} \mathrm{C}$ and $32^{\circ} \mathrm{C}$ using a TC-324B control unit (Warner Instruments). L5 pyramidal neurons of the $\mathrm{mPFC}$ contralateral to the site of surgery were visualized using an upright microscope (Olympus) with oblique illumination and video microscopy using a digital camera (DVC). L5 cells were identified according to location, size, and shape and were filled with biocytin for subsequent histological processing. Because the mPFC is heterogeneous, we made an effort to ensure that the cell populations from sham and SNI animals were homogenous. This was achieved by monitoring cell location and cell-firing pattern. All cells analyzed in this study were located between 525 and $1159 \mu \mathrm{m}$ from pia in the $\mathrm{mPFC}$ (as assessed using online imaging of patched neurons). In 

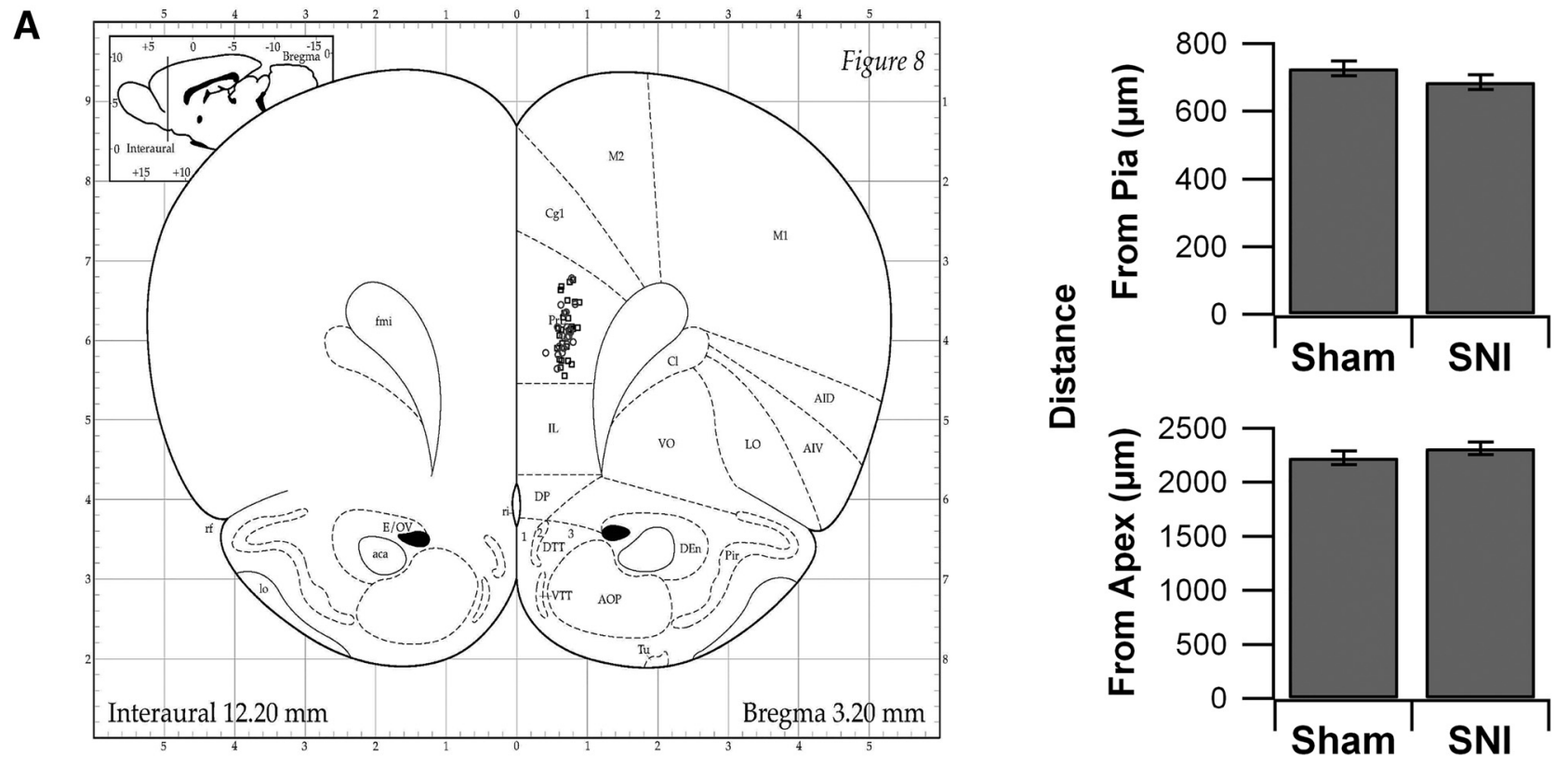

B
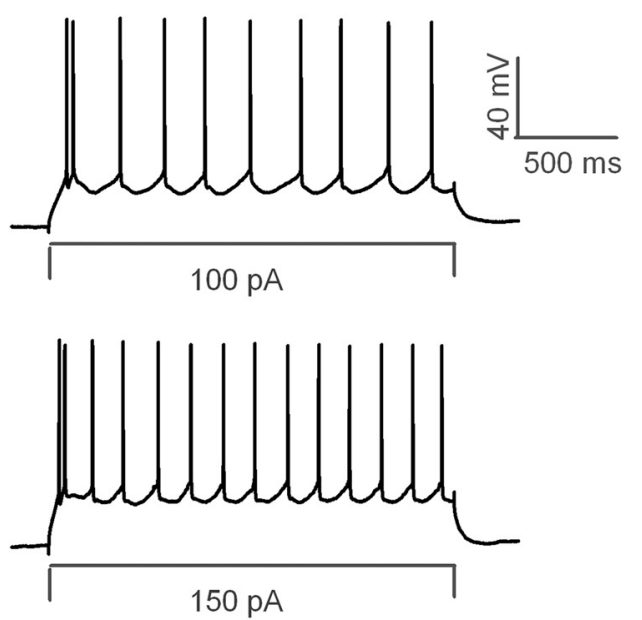
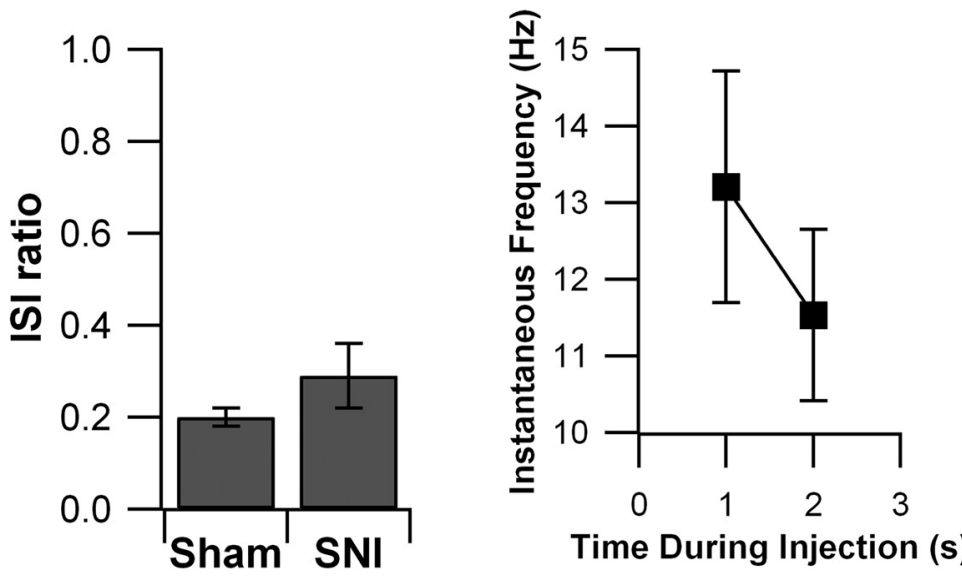

Figure 2. Location and firing properties of the recorded MPFC L5 pyramidal neurons. A, All current-clamp (and a subset of voltage-clamp) recorded cells were filled with biocytin; the positions were then mapped onto an image of the mPFC (Paxinos and Watson, 1998) and plotted as a function of distance from pia ( $x$-axis) and distance from apex ( $y$-axis). (ell bodies of sham neurons were located at a distance of $726.4 \pm 22 \mu \mathrm{m}$ from the pia and $2227 \pm 61.6 \mu \mathrm{m}$ from the apex $(n=31)$. SNI neurons were located $685.6 \pm 22 \mu \mathrm{m}$ from pia and $2315.7 \pm 57 \mu \mathrm{m}$ from apex $(n=22)$, in the prelimbic region of the rat $\mathrm{mPFC} . \boldsymbol{B}$, Left, Current-clamp recordings in slices from sham and SNI rats. Middle, Cells from both sham and SNI animals exhibited accommodation, as evidenced by interspike interval ratios (first interspike interval divided by the average interval) of $0.2 \pm 0.02$ and $0.29 \pm 0.07$ ( $n=10,9$, respectively) and a time-dependent reduction in instantaneous firing frequency in response to a current injection of $150 \mathrm{pA}(13.21 \pm 1.51 \mathrm{~Hz}$ at $1 \mathrm{~s}$, and $11.53 \pm 1.12 \mathrm{~Hz}$ at $2 \mathrm{~s}$, paired $t$ test $p=0.01 ; n=19 ;$ right).

addition, the locations of all of the neurons used for current-clamp experiments and a subset of those for the voltage-clamp experiments were also confirmed by post hoc examination of biocytin-filled cells. These neurons are plotted relative to distance from pia and apex and shown in Figure $2 A$. For somata of cells from sham-operated rats, the main distance from pia and apex was $726.4 \pm 22 \mu \mathrm{m}$ and $2227 \pm 61.6 \mu \mathrm{m}$, respectively $(n=31)$; neurons from SNI rats were located $685.6 \pm 22 \mu \mathrm{m}$ from pia and $2315.7 \pm 57 \mu \mathrm{m}$ from apex $(n=22)$. L5 mPFC neurons comprise two main populations, one projecting to the pons and one to the contralateral cortex (COM). These two populations can be separated on the basis of their firing properties (Dembrow et al., 2010). According to these parameters, all cells used for our current-clamp recordings could be classified as COM because they exhibited accommodating firing patterns and were all capable of firing with $100 \mathrm{pA}$ depolarizing current injections from a membrane potential of $-65 \mathrm{mV}$ (Fig. 2B). Cells recorded in voltage clamp, however, could not be classified functionally because the internal solution contained Cs-methanesulfonate and QX314. However, we found no evidence for cellular heterogeneity with regard to ACh response between L5 pyramidal neurons. All recordings were performed using an Axopatch 200B amplifier. Signals were filtered at $10 \mathrm{kHz}$ and sampled at $20 \mathrm{kHz}$ for current-clamp recordings and filtered at $5 \mathrm{kHz}$ and sampled at $10 \mathrm{kHz}$ for voltage-clamp recordings. Traces presented in the figures represent single sweeps or the average of up to three sweeps. Pipettes were pulled from WPI glass (PG10-165) using a horizontal puller (P97; Sutter Instruments) and were filled with an internal solution consisting of either Cs-methanesulfonate for voltage-clamp experiments containing the following (in mM): $138 \mathrm{Cs}$ methanesulfonate, $10 \mathrm{HEPES}, 0.1 \mathrm{EGTA}, 4 \mathrm{NaCl}, 2 \mathrm{MgCl}_{2}$, $2 \mathrm{ATP}, 0.3$ GTP, and 5 QX, along with biocytin $(1 \mathrm{mg} / \mathrm{ml}), \mathrm{pH} 7.33$ with $\mathrm{CsOH}$ or, for current-clamp experiments: $140 \mathrm{~K}$-gluconate, $10 \mathrm{HEPES}, 0.1 \mathrm{EGTA}$, $8 \mathrm{NaCl}, 2 \mathrm{MgCl}_{2}, 2 \mathrm{ATP}$, and $0.3 \mathrm{GTP}$, along with biocytin (1 mg/ml), pH 7.35 with $\mathrm{KOH}$. Pipette resistances in the working solutions ranged from 
3 to $6 \mathrm{M} \Omega$, yielding series resistances of 10-30 M $\Omega$. Pipettes of comparable tip size were used for focal application of ACh $(0.1$ or $1 \mathrm{~mm})$ dissolved in a HEPES (Sigma-Aldrich)-buffered extracellular solution, $\mathrm{pH}$ $\sim 7.32$ with $\mathrm{NaOH}$, and containing blockers of fast excitatory and inhibitory synaptic transmission.

To characterize the effect of ACh on neuronal excitability, we used a picospritzer (Parker) to deliver short pulses (100 ms) of ACh to the soma of pyramidal neurons from animals that had received either the SNI or sham surgery. ACh pulses were delivered at $60 \mathrm{~s}$ intervals to allow recovery from receptor desensitization. In control conditions, with fast synaptic transmission pharmacologically blocked (20 $\mu \mathrm{M}$ DNQX, $50 \mu \mathrm{M}$ APV, and $100 \mu \mathrm{M}$ picrotoxin), 2-s-long current injections of 50, 100 and 150 $\mathrm{pA}$ were delivered to evoke trains of action potentials. Input/output (I/O) curves were calculated by measuring the number of spikes elicited in response to a $2 \mathrm{~s}$ depolarizing current step delivered either in control conditions or $3 \mathrm{~s}$ after a $100 \mathrm{~ms}$ pulse of somatically applied ACh. The curves were then fitted with a Boltzmann function of the following form:

$$
f(I)=1 /\left[1+\exp \left(-\left(I-I_{1 / 2}\right) / k\right)\right]
$$

where $I$ is the injected current, $I_{1 / 2}$ is the current injection at which the value of the function is 0.5 , and $k$ is the slope factor.

Drug stock solutions. DNQX (20 mM) and APV (50 mM) were dissolved in water and stored at $-30^{\circ} \mathrm{C}$. Picrotoxin $(50 \mathrm{~mm})$ was dissolved in dimethylsulfoxide (DMSO) and stored at $4^{\circ} \mathrm{C}$. ACh (100 mM), $\mathrm{CdCl}_{2}(1 \mathrm{M})$, and $\mathrm{Ba}^{2+}(1 \mathrm{M})$ were prepared in water and stored at $4^{\circ} \mathrm{C}$. Atropine $(2$ $\mathrm{mM})$, pirenzepine $(10 \mathrm{~mm})$, and methoctramine ( $1 \mathrm{mM}$ ) were prepared in water and stored at $-30^{\circ} \mathrm{C}$. Fresh working solutions were prepared on the day of the experiment. DNQX, APV, picrotoxin, atropine, and ACh were from AbCam; pirenzepine was from R\&D Research; all other chemicals were from Sigma-Aldrich.

Post hoc anatomical visualization of patched cells. After the patchclamp recordings, cells were fixed for $2-4 \mathrm{~h}$ at room temperature in $4 \%$ paraformaldehyde in $0.1 \mathrm{M}$ phosphate buffer $(\mathrm{PB}, \mathrm{pH} 7.4)$ and then stored at $4^{\circ} \mathrm{C}$ in $\mathrm{PBS}, \mathrm{pH} 7.4$, until processing. Biocytin-filled cells were processed using a standard 3,3-diaminobenzidine (DAB) protocol. Slices were rinsed in PBS, treated with hydrogen peroxide for 20-30 min, and permeabilized with $2 \%$ Triton X-100 for $1 \mathrm{~h}$. They were then incubated overnight at $4^{\circ} \mathrm{C}$ in PBS containing $1 \%$ avidin-biotinylated horseradish peroxidase complex (ABC; Vector Labs). After the primary incubation, slices were washed with PBS, developed by $0.1 \%$ DAB (Sigma-Aldrich) exposure for $\sim 5 \mathrm{~min}$, and washed again multiple times in fresh PBS before being mounted on a slide and embedded with Mowiol (SigmaAldrich). Cell location was quantified based on the distances of the cell body from the pia and distance from the apex of the cortical section.

$q R T-P C R$. Coronal slices of mPFC were cut in ice-cold ACSF; the L5 contralateral to SNI was dissected out, frozen in liquid nitrogen, and stored until being processed for PCR. RNA was extracted using a Qiagen RNeasy RNA extraction kit (\#74136); DNA contamination was prevented by first using a column that binds DNA while allowing RNA to flow through. RNA was reverse transcribed into cDNA using Roche's First Strand cDNA Synthesis kit using both oligo dT and random hexamer primers according to the manufacturer's protocol (\#04897030001). RNA yield and quality were confirmed with Nanodrop analysis.

qRT-PCR was performed using a Roche Lightcycler 480 (LC480) with SYBR Green I Master Mix (\#04707516001), primers $(0.4 \mu \mathrm{M})$, and mPFC cDNA. All genes of interest were normalized to the GAPDH reference gene. Reactions consisted of a $5 \mathrm{~min}$ hot start incubation at $95^{\circ} \mathrm{C}$, followed by 45 cycles of $10 \mathrm{~s}$ at $95^{\circ} \mathrm{C}, 10 \mathrm{~s}$ at $60^{\circ} \mathrm{C}$, and $10 \mathrm{~s}$ at $72^{\circ} \mathrm{C}$. Melting temperature analysis demonstrated a single peak for each gene product. Although most primers were intron spanning, cDNA-negative and reverse transcriptase-negative controls were done for all genes of interest. As recommended in published guidelines for qRT-PCR methods, all data were efficiency corrected (Bustin et al., 2010). Standard curves were obtained for each primer pair to calculate reaction efficiency for each gene product using progressive dilutions of cDNA. All data were efficiency corrected using Roche LC480 software and the delta delta Ct method (Livak and Schmittgen, 2001) (Schmittgen and Livak, 2008). Within the recommendations of the MIQE qRT-PCR guidelines (Bustin et al.,
2010), a reference gene can be validated by running another reference gene against it. Therefore, to validate GADPH as a stable reference gene, tubulin was run relative to GAPDH for all samples and no significant differences in tubulin were detected when run against GAPDH (data not shown). Statistical analyses were done using a two-way ANOVA test, with Fisher LSD for post hoc analysis. The following primers were used: acetylcholinesterase (NM_172009.1, f-5' ttaatgtgtggacaccataccc 3', r-5' tgcataagtcgctgagcaaa $3^{\prime}$ ), cholinergic muscarinic receptor 1 (NM_080773.1,f-5' gcctacagctggaaggaaga $3^{\prime}, \mathrm{r}-5^{\prime}$ cggaggatgtgagggactc $3^{\prime}$ ), TRPCA (NM_001083115.1, f-5' ccatgatcagagaggcaaaaa $3^{\prime}, \mathrm{r}-5^{\prime}$ gctagaaatgtcttgctttagttcc $3^{\prime}$ ), TRPC5 (NM_080898.2, f-5 caactcctaccagctcattgc $3^{\prime}$, r-5' ggctggggatgatgttga $3^{\prime}$ ), TRPC6 (NM_053559.1) f-5' gcagctgttcaggatgaaaac $3^{\prime}, \quad r-5^{\prime}$ acattcagcccatatcattccta $\left.3^{\prime}\right)$, TRPM4 (NM_001136229.1, f-5' acttggaaccagtgcgactt $3^{\prime}, \mathrm{r}-5^{\prime}$ aaacaggccaggagtcagc $3^{\prime}$ ), TRPM5 (NM_001191896.1, f-5 ${ }^{\prime}$ atccttcaccgccaacttct $3^{\prime}, \mathrm{r}-5^{\prime}$ gcagaggggtccctgagt $\left.3^{\prime}\right)$, GAPDH (f-5' ctgcaccaccaactgcttag $3^{\prime}, \mathrm{r}-5^{\prime}$ tgatggcatggactgtgg $\left.3^{\prime}\right), \alpha$ tubulin $1 \mathrm{~B}$ (f-5' cttctaacccgtagctatcatgc $3^{\prime}, \mathrm{r}-5^{\prime}$ gccatgttccaggcagtag $\left.3^{\prime}\right)$, and Nav1.9 (f-5' gcgaagacttcataatgtgtgg $3^{\prime}, \mathrm{r}-5^{\prime}$ cacgtagaaccattgggaca $3^{\prime}$ ).

Total protein level and subcellular brain fractionation. Biochemical fractionation was performed following standard methods as described previously (Hallett et al., 2008; Sanz-Clemente et al., 2010). Briefly, the contralateral L5 mPFC was microdissected and each sample contained tissue obtained from three different mice. Samples were then homogenized in ice-cold buffer (10 mM Tris, pH 7.5, 1 mM EDTA) containing $0.32 \mathrm{M}$ sucrose, protease inhibitors (\#11836145001; Roche) and phosphatase inhibitors (mixture 2 and 3, \#P5726 and \#P0044; Sigma-Aldrich). Samples were centrifuged for $10 \mathrm{~min}$ to $1000 \times g$ at $4^{\circ} \mathrm{C}$ to remove nuclei and large debris and, after removing an aliquot (total homogenate), the supernatant was subsequently centrifuged to $10,000 \times g$. Pellet (synaptosomes) was resuspended in hypoosmotic buffer (10 mM Tris, $\mathrm{pH} 8.8,1$ mM EDTA), briefly sonicated, and incubated at $4^{\circ} \mathrm{C}$ for $10 \mathrm{~min}$ with gentle rotation. Samples were centrifuged $30 \mathrm{~min}$ at $25,000 \times g$ to collect SPMs in the pellet. SPMs were dissolved in PBS containing 1\% SDS; the protein concentration in total homogenate and SPM samples was quantified using the BCA assay (Pierce). Ten micrograms of proteins per sample were separated by SDS-PAGE and analyzed by immunoblotting.

Surface biotinylation in acute cortical slices. Three-hundred-micrometer acute cortical slices were prepared from sham or SNI rats in icecold ACSF $\left(0.5 \mathrm{mM} \mathrm{Ca}^{2+}, 7 \mathrm{mM} \mathrm{Mg}^{2+}\right)$, incubated for $30 \mathrm{~min}$ in ice-cold ACSF containing $0.5 \mathrm{mg} / \mathrm{ml}$ biotin (EZ-link-Sulfo-NHS-LC-Biotin; Thermo Scientific), and equilibrated with $95 \% \mathrm{O}_{2}, 5 \% \mathrm{CO}_{2}$. After two washes with ice-cold oxygenated ACSF containing $50 \mathrm{mM} \mathrm{NH}_{4} \mathrm{Cl}$ and two washes with ice-cold oxygenated ACSF, L5 mPFC was dissected out and frozen in liquid nitrogen. Again, each sample contained tissue obtained from three different mice. Samples were homogenized as above and centrifuged at $1000 \times \mathrm{g}$ for $10 \mathrm{~min}$ at $4^{\circ} \mathrm{C} ; 10 \%$ Triton $\mathrm{X}-100$ was then added to the supernatant to obtain a final Triton X-100 concentration of $1 \%$ and the sample tubes were inserted in a vertical wheel to provide continuous rotation and incubated for $10-15 \mathrm{~min}$ at $4^{\circ} \mathrm{C}$. The samples were centrifuged for $45 \mathrm{~min}$ at $100,000 \times \mathrm{g}$ at $4^{\circ} \mathrm{C}$ to remove insoluble material and, after taking an aliquot (input), the supernatant was incubated with rotation for $2 \mathrm{~h}$ at $4^{\circ} \mathrm{C}$ with $20 \mu \mathrm{l}$ of NeutrAvidin Agarose Resin (Thermo Scientific). After 3 washes with PBS 1\% Triton $\mathrm{X}-100$, recovered material was subjected to immunoblotting.

Immunoblotting. Proteins were separated in $9 \%$ acrylamide gels by SDS-PAGE and transferred to a $0.45 \mu \mathrm{m}$ PVDF membrane. Membranes were blocked in TBS-T (TBS with $0.1 \%$ Tween 20 ) containing $5 \%(\mathrm{w} / \mathrm{v})$ nonfat skim milk before incubation with primary antibodies in TBS-T. After 3 washes with TBS-T, membranes were incubated with HRPconjugated anti-mouse or anti-rabbit secondary antibodies $(1: 10,000$; GE Healthcare). Signal was detected in an Azure c300 imager after incubation 5 min with SuperSignal West Pico Chemiluminescent Substrate (Thermo Scientific) and intensity was quantified using ImageJ software. The antibodies used were obtained from Santa Cruz Biotechnology (anti-actin \#sc47778, RRID:AB_626632), Millipore (anti-M1 muscarinic ACh receptor antibody \#AB5164, RRID:AB_91713; antiGluA2 \#MAB397), and Invitrogen (anti-Transferrin Receptor, clone H68.4, \#13-6800). 
A

Sham
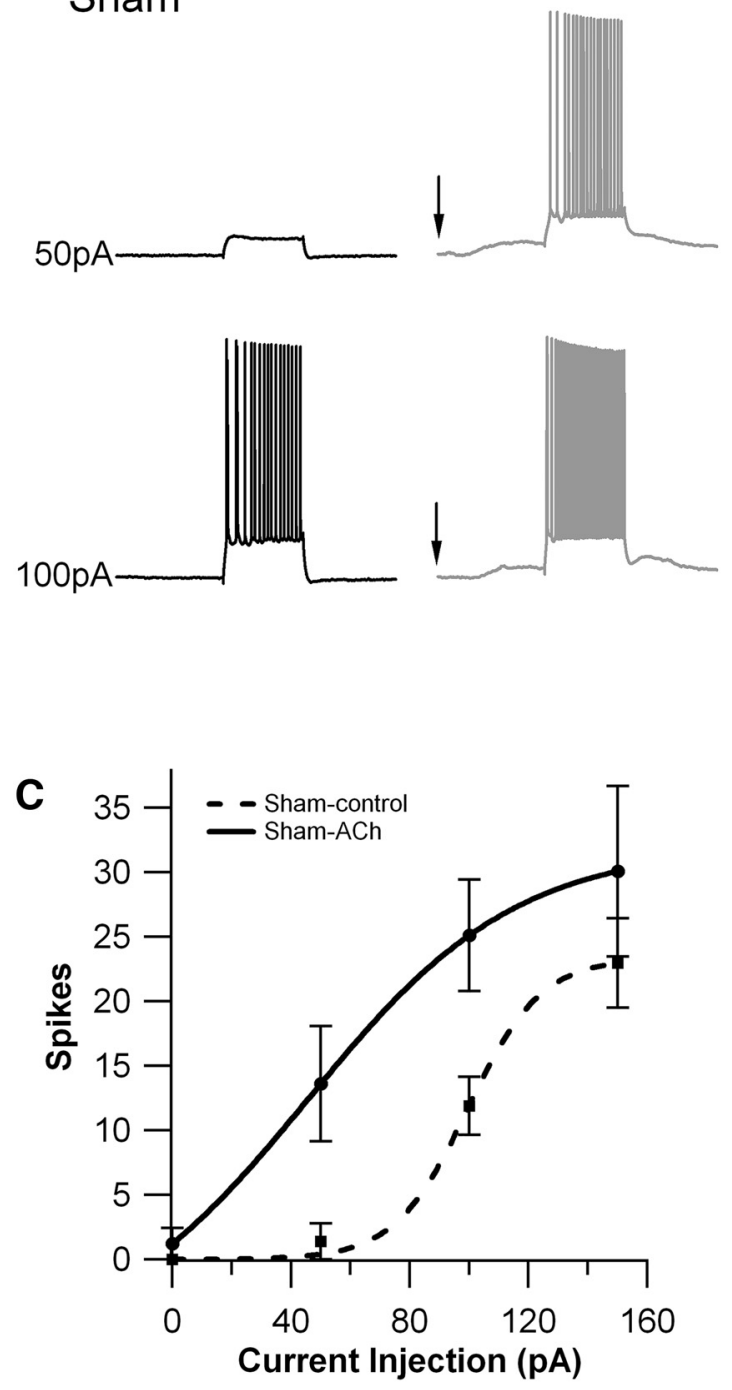

B

\section{SNI}
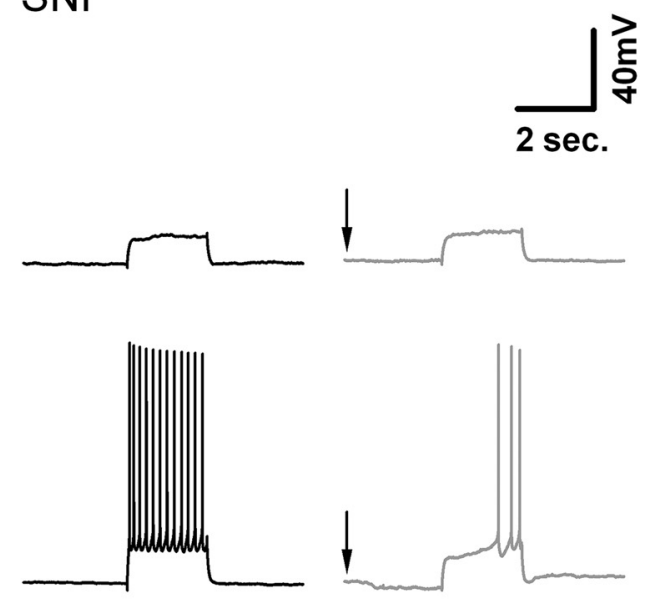

D

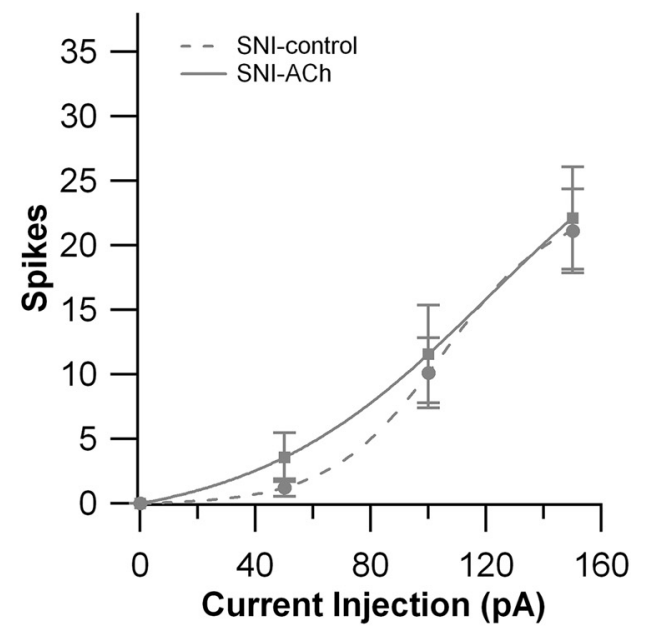

Figure 3. ACh increases pyramidal cell excitability in sham, but not $S \mathrm{NI}$, animals. $A$, Voltage responses recorded from $L 5$ pyramidal neurons in acute slices in the presence of blockers of fast synaptic transmission (100 $\mu \mathrm{m}$ picrotoxin, $20 \mu \mathrm{M}$ DNQX, $50 \mu \mathrm{M} \mathrm{APV}$ ); cells were stimulated with $2 \mathrm{~s}$ current injections of either 50 or $100 \mathrm{pA}$ in control conditions (black) and after a $1 \mathrm{~mm}, 100 \mathrm{~ms}$ focal application of ACh (black; arrow indicates the time of ACh application) in a slice from a sham animal. At rest, both neurons were held at $-70 \mathrm{mV}$. $\boldsymbol{B}$, In slices from SNI animals, the same stimulation protocol failed to increase cellular excitability in response to a $50 \mathrm{pA}$ current injection and actually decreased excitability in response to a $100 \mathrm{pA} \mathrm{current} \mathrm{injection} \mathrm{(gray)} \mathrm{compared} \mathrm{with} \mathrm{control} \mathrm{conditions} \mathrm{(black).}$ C, In sham rats, ACh application induced a leftward shift in the I/ 0 curve. Fitting the data points with Boltzmann equations showed that ACh shifted the midpoint from $99.5 \pm 8.1 \mathrm{pA} \mathrm{to} 45 \pm 6.3 \mathrm{pA}(n=10)$. D, ACh failed to shift the l/0 curve of pyramidal neurons from SNI animals (gray) $\left(I_{1 / 2}=104.9 \pm 7.8 \mathrm{pA}\right.$, in control and $120.9 \pm 14.2 \mathrm{pA}$ in ACh, in SNI cells, $\left.n=9\right)$.

\section{Results}

ACh enhancement of L5 pyramidal neuron firing is blunted in SNI animals

In the brain, $\mathrm{ACh}$ acts as a neuromodulator and regulates intrinsic excitability and synaptic transmission. We investigated the effect of ACh on the response of pyramidal cells to depolarizing current injections in brain slices from control and SNI animals. Whole-cell patch-clamp recordings were obtained from L5 pyramidal neurons in the PL region of the rat mPFC (Fig. 2). In control conditions (no ACh), cells from sham and SNI animals showed similar firing patterns and responded to $100 \mathrm{pA}$ depolarizing current injections ( $2 \mathrm{~s}$ ) with train of action potentials at a frequency of $5.1 \pm 1.4 \mathrm{~Hz}$ for cells from sham and $6.0 \pm 1.1 \mathrm{~Hz}$ for SNI (10 and 9 cells, respectively), whereas $50 \mathrm{pA}$ injections seldom elicited firing (Fig. $3 A, B$, black traces). Focal application of ACh, however, had dramatically different effects in the two experimental groups. In sham animals, ACh (1 mM, $100 \mathrm{~ms}$, at the soma) strongly increased cellular excitability by causing a leftward shift in the I/O curve (Fig. 3A,B, gray traces; arrows indicate the time of ACh application). In sham animals, ACh increased the number of spikes elicited by $50 \mathrm{pA}$ depolarizing current injection by $\sim 10$ fold, from $0.7 \pm 0.7 \mathrm{~Hz}$ to $6.8 \pm 2.2 \mathrm{~Hz}$ ( 10 cells). Fitting the averaged I/O curve with a Boltzmann function revealed that, in cells from sham animals, ACh caused an $\sim 55 \mathrm{pA}$ leftward shift in the midpoint of the curve from $99.5 \pm$ $8.1 \mathrm{pA}$ in control conditions to $45.0 \pm 6.3 \mathrm{pA}$ after ACh application ( $p=0.006$; Fig. $3 C$ ). Surprisingly, the ACh effect was almost completely eliminated in pyramidal neurons from SNI animals, in which no effect on either the $\mathrm{I} / \mathrm{O}$ curve or the total number of spikes was detected (Fig. 3D).

The differential effect of ACh on sham and SNI neurons included another important functional modulation. Consistent with previous findings showing that ACh elicits an SADP following a train of action potentials (Haj-Dahmane and Andrade, 
A

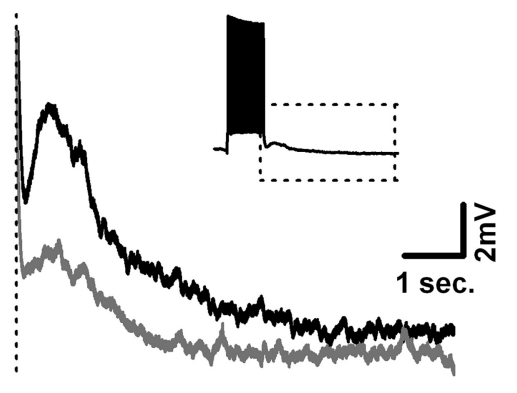

B

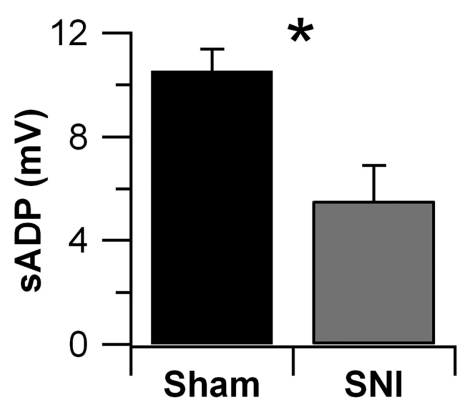

C

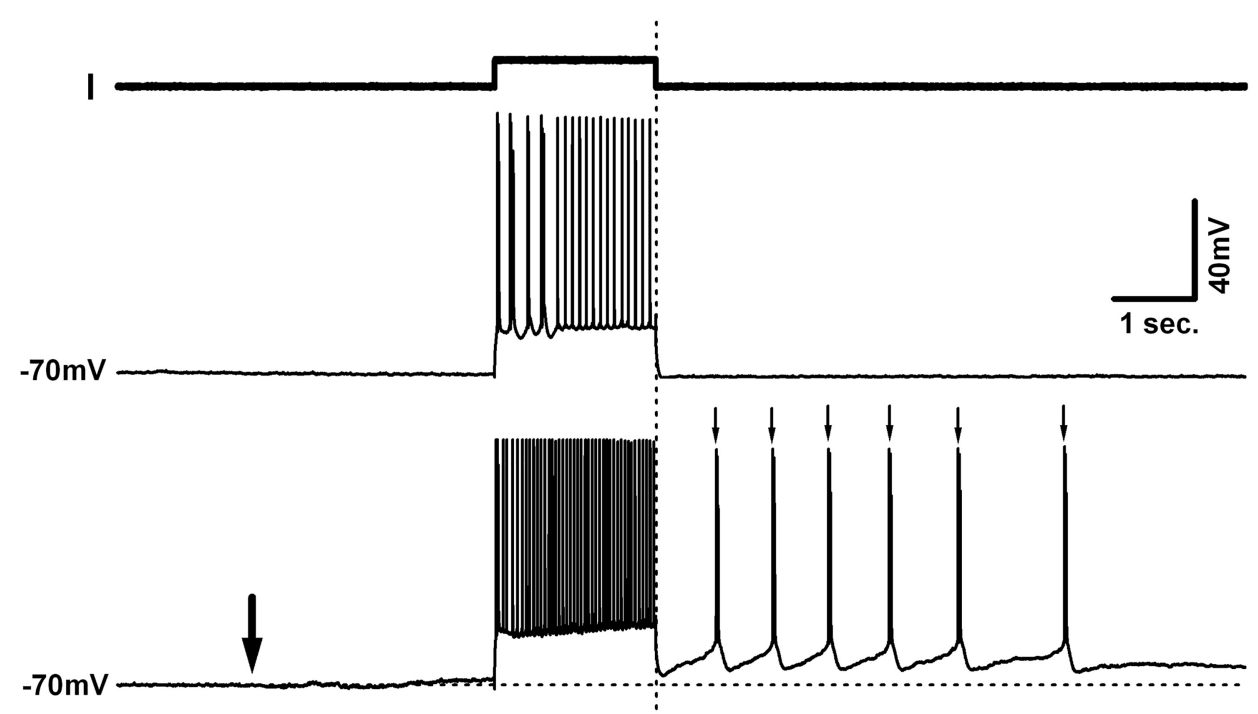

D
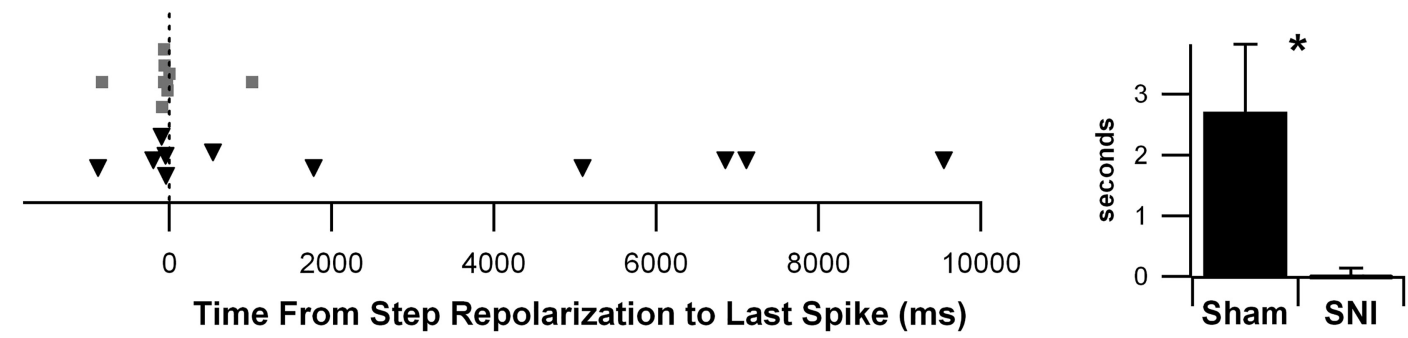

Figure 4. ACh-mediated persistent firing is abolished in SNI animals. A, Whole-cell, current-clamp traces of an ACh-dependent sADP response immediately after a $100 \mathrm{pA}, 2$-s-long current injection (inset) in a cell from a sham (black) and a $150 \mathrm{pA}, 2$-s-long current injection from a SNI (gray) rat. $\boldsymbol{B}$, Average of the maximum peak sADP voltage response in sham and SNI animals (10.55 \pm $0.8 \mathrm{mV}$ and $5.5 \pm 1.4 \mathrm{mV}, n=7$ and 9 , respectively, $p=0.01$ ). C, Top trace, Current-clamp response of a mPFC pyramidal neuron to a $150 \mathrm{pA}, 2$ s current injection in control conditions. Bottom trace, Voltage response of an $\mathrm{mPFC}$ pyramidal neuron to $1 \mathrm{~mm}, 100 \mathrm{~ms}$ focal application of ACh (large arrow), followed by a $150 \mathrm{pA}, 2 \mathrm{~s}$ current injection. Note the persistence of action potentials (small arrows) after the end of the current step. $\boldsymbol{D}$, Left, Time, relative to the end of the current step (time 0 , dashed line), of the last recorded action potential after focal application of ACh plotted for both sham and SNI animals. Note that, in 55\% of the tested pyramidal neurons from sham animals, persistent activity was observed for several seconds after the end of the current step. Right, Average time, in seconds, of the last recorded action potential relative to step repolarization after focal application of ACh in sham and SNI animals $(2.7 \pm 1.1 \mathrm{~s}$ and $-0.015 \pm 0.16 \mathrm{~s}$, respectively, $n=11$, $9 p=0.036)$.

1999; Lei et al., 2014), ACh elicited an sADP in L5 neurons from both sham and SNI animals (Fig. 4). However, in cells from SNI rats, the ACh-dependent sADP was significantly smaller $(5.5 \pm$ $1.4 \mathrm{mV}$ versus $10.6 \pm 0.8 \mathrm{mV}$ in sham; 9 and 7 cells, respectively, $p=0.01$; Fig. $4 B$ ). In addition, we found that, in slices from sham animals, focal application of ACh ( $1 \mathrm{~mm}, 100 \mathrm{~ms}) 3 \mathrm{~s}$ before a 2 -s-long depolarizing current injection often caused the firing response to last well beyond the end of the current stimulus ( 6 of 11 neurons; Fig. 4C,D). In slices from SNI animals, however, this prolonged firing response was observed in only one of nine cells (Fig. 4D) and, in the only SNI cell in which it was detected, it was limited to a single spike after the end of the stimulus. On average, the time of the last observed spike relative to the end of the step current injection was $+2918 \pm 1219 \mathrm{~ms}$ in sham and $-15 \pm 156$ $\mathrm{ms}$ in SNI cells $(p=0.04$; Fig. $4 D)$. Therefore, ACh-induced persistent firing is virtually abolished in the SNI condition.

Prolonged depolarization induced by ACh in L5 mPFC pyramidal neurons is reduced in SNI animals

The persistent firing in response to short applications of ACh is intriguing. To investigate the mechanisms underlying this phenomenon, we performed current-clamp recordings to measure 
A

$$
\text { ACh }
$$
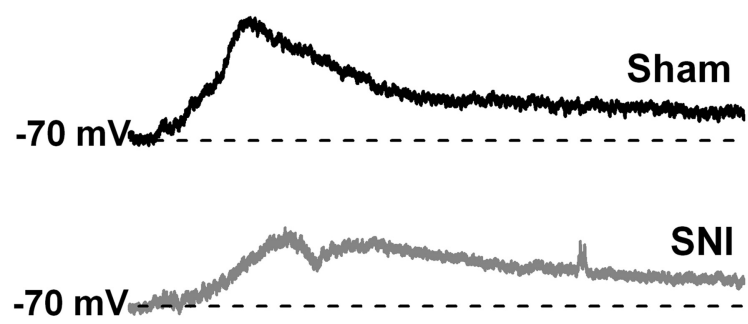
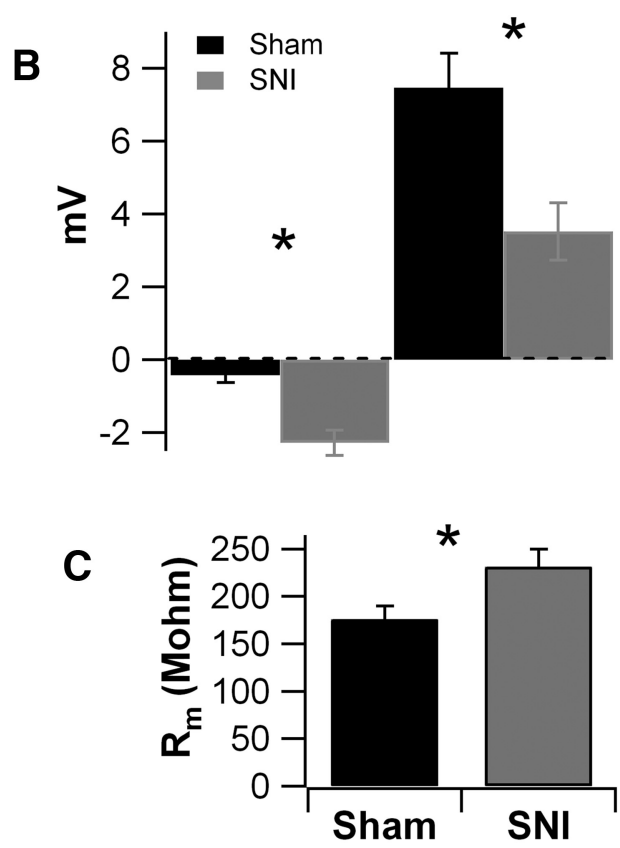

D

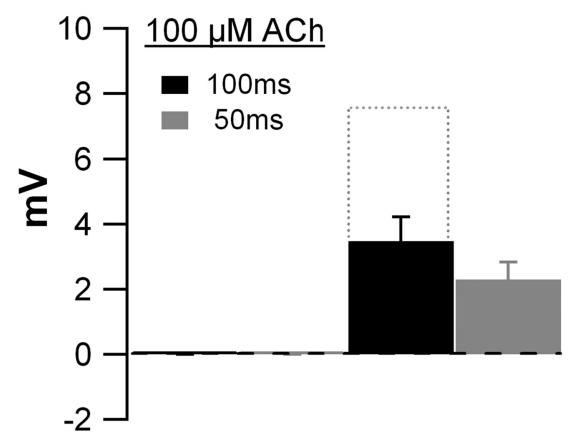

$\mathbf{E}$

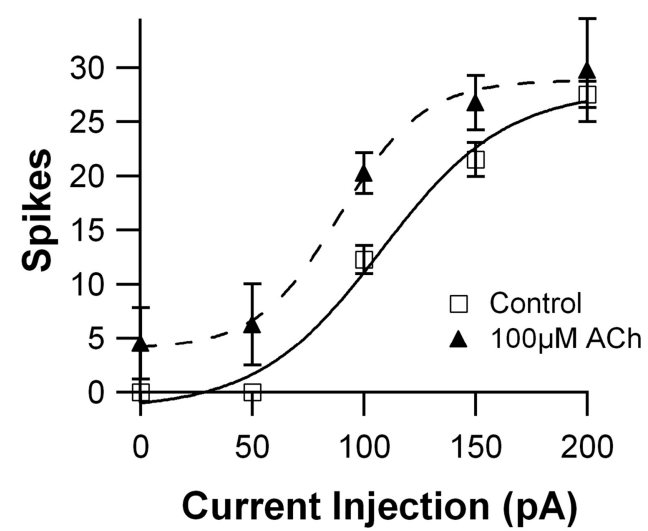

Figure 5. ACh induced depolarization is blunted in SNI animals. A, Voltage responses of $\mathrm{L} 5$ pyramidal neurons to 100 -ms-long focal applications of $\mathrm{ACh}(1 \mathrm{~mm}$, at the soma) in slices from sham and SNI animals. The bath temperature was $\sim 31^{\circ} \mathrm{C}$ and the resting potential $-70 \mathrm{mV}$, in both cells. The resting membrane potential was kept at $-70 \mathrm{mV}$ in all cells (if necessary, a small holding current was injected). In some cells, the ACh-dependent depolarization was preceded by a hyperpolarization (bottom, gray). $\boldsymbol{B}$, Left, When present, the average hyperpolarizing responses to ACh (1 $\mathrm{mm}$ ) were significantly different in sham animals (black, $-0.42 \pm 0.19 \mathrm{mV}, 11$ cells) and SNI animals (gray, $-2.28 \pm 0.34 \mathrm{mV}, 9$ cells, $p=0.017$ ). Right, Average depolarizing voltage responses to ACh (1 mM) were significantly different between sham (black, $7.47 \pm 0.95 \mathrm{mV}, n=11$ ) and SNI animals (gray, $3.50 \pm 0.78 \mathrm{mV}, n=9, p=0.005$ ). $C$, Membrane resistance in SNI cells was larger compared with sham $(231.0 \pm 19 \mathrm{M} \Omega$ and $176.08 \pm 14.0 \mathrm{M} \Omega$, respectively, $n=9$ and 10, respectively, $p=0.03)$. D, Responses evoked by focal application of $100 \mu \mathrm{m} \mathrm{ACh}$ were $3.48 \pm 0.7 \mathrm{mV}$ after $100 \mathrm{~ms}$ applications ( 10 cell from naive animals) and $2.3 \pm 0.5 \mathrm{mV}$ in response to $50 \mathrm{~ms}$ applications ( 7 cells from naive animals). The gray dotted bar shows, for comparison, the depolarizing response observed in sham animals using $1 \mathrm{~mm} \mathrm{ACh}$. Note that no hyperpolarizing component was detectable with the reduction in ACh concentration and duration. $\boldsymbol{E}$, Focally applied ACh (100 $\mu \mathrm{m}$ ) caused an increase in the firing frequency (in response to a $100 \mathrm{pA}$ current injection it was $6.1 \pm 0.7 \mathrm{~Hz}$ in control versus $10.1 \pm 0.9 \mathrm{~Hz}$ in $100 \mu \mathrm{m} \mathrm{ACh}, p=0.02 ; 4$ cells from naive animals).

the voltage response evoked by ACh application ( $1 \mathrm{~mm}, 100 \mathrm{~ms}$, delivered at $60 \mathrm{~s}$ intervals to allow for the recovery of the response) to the soma of pyramidal neurons from animals that had received either the SNI or sham surgery.

Focal ACh application to L5 prelimbic pyramidal neurons elicited a slow-activating, long-lasting net depolarizing response in both sham and SNI animals (Fig. 5A). The initial resting membrane potential was $-70 \mathrm{mV}$ (if necessary, a small holding current was injected). We observed no difference in the resting membrane potential between sham and SNI animals (data not shown). The peak positive voltage responses were reached $\sim 3 \mathrm{~s}$ after the ACh pulses and decayed with a time constant of $9.1 \pm$ $2.3 \mathrm{~s}$ ( 10 cells from sham rats). In $50 \%$ of sham and $80 \%$ of SNI neurons tested, the depolarizing voltage response was preceded by a hyperpolarizing response (Fig. $5 A$, bottom). Interestingly, neurons from SNI animals exhibited, on average, a significantly larger hyperpolarizing response and a significantly reduced depolarizing response compared with their sham counterparts (Fig. $5 B)$. The average peak depolarizing response to $1 \mathrm{mM} \mathrm{ACh}$ was $7.47 \pm 0.95 \mathrm{mV}$ in sham animals and $3.5 \pm 0.8 \mathrm{mV}$ in SNI $(n=$ 11,9 respectively, $p=0.01$ ), whereas the average hyperpolarizing response was $-0.42 \pm 0.2 \mathrm{mV}$ in sham animals and $-2.28 \pm 0.3$ $\mathrm{mV}$ in SNI $(n=11,9 p=0.02)$. Consistent with recent findings (Kelly et al., 2016), the membrane resistance of SNI cells was larger compared with sham (at $-70 \mathrm{mV}$, it was $231 \pm 19 \mathrm{M} \Omega$ in SNI vs $176 \pm 14.0 \mathrm{M} \Omega$ in sham animals, 10 and 9 cells, respectively, $p=0.03$ ); therefore, the observed reduction in the depolarizing voltage responses cannot be attributed to a reduced 
A

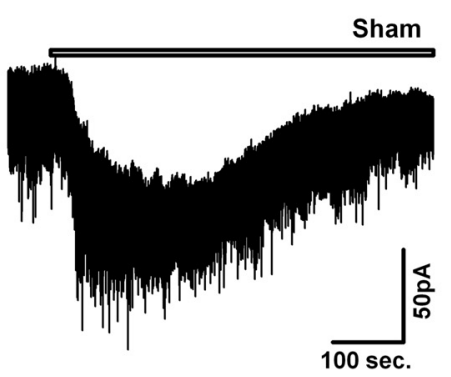

C

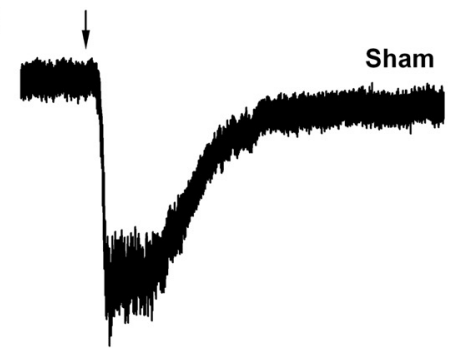

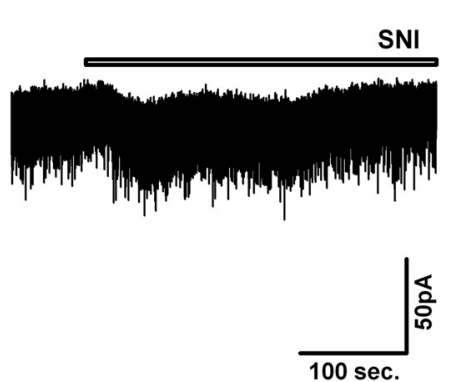
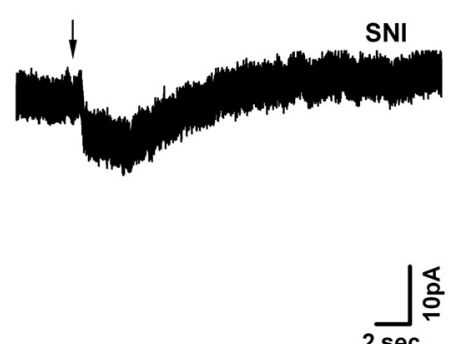

B

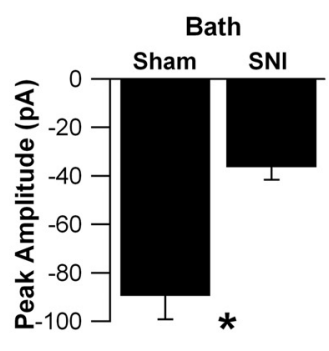

Figure 6. ACh-evoked currents in L5 pyramidal neurons are markedly reduced in mPFC of SNI rats. $\boldsymbol{A}$, Whole-cell, current traces in sham (left) and SNI (right) pyramidal neurons voltage clamped at $-70 \mathrm{mV}$ after bath application of $1 \mathrm{~mm} \mathrm{ACh}$ (bar). The bath solution contained $100 \mu \mathrm{m}$ picrotoxin to block fast, inhibitory synaptic currents. $\boldsymbol{B}$, Average peak current responses evoked by bath application of $1 \mathrm{~mm} \mathrm{ACh}$ in sham $(-89.5 \pm 9.6 \mathrm{pA}, n=10)$ and SNI $(-36.5 \pm 5.2 \mathrm{pA}, n=10, p=0.0003)$ animals. When individual peak current responses are normalized to the capacitance of the cell, the difference between sham and SNI responses remains significant $(0.70 \pm 0.09 \mathrm{pA} / \mathrm{pF}$ and $0.25 \pm 0.03, n=10$ and 10 , respectively, $p=0.0014)$. C, Current traces in sham (left) and SNI (right) neurons voltage clamped at $-70 \mathrm{mV}$ after a $1 \mathrm{~mm}, 100 \mathrm{~ms}$ picospritzer application of ACh (arrow). Bath and focal application solution contained blockers of fast excitatory ( $50 \mu \mathrm{m}$ APV and $20 \mu \mathrm{m} \mathrm{DNQX)}$ and inhibitory synaptic currents (100 $\mu \mathrm{m}$ picrotoxin). D. Average peak current responses evoked by $1 \mathrm{~mm} \mathrm{ACh} \mathrm{in} \mathrm{sham} \mathrm{(}-32.57 \pm 1.98 \mathrm{pA}, n=27)$ and SNI ( $-18.81 \pm 2.69 \mathrm{pA}$, $n=18, p=0.0015)$ animals.

membrane resistance in the SNI cells. We also tested whether the net excitatory responses in control animals depend on the particular ACh concentration used or the application duration. Reducing the ACh concentration 10-fold, from $1 \mathrm{mM}$ to $100 \mu \mathrm{M}$, resulted in a reduced, but still depolarizing, voltage response (3.48 $\pm 0.7 \mathrm{mV}, n=10$, recorded in cells from naive animals; Fig. $5 D$, black). Reducing the duration of application from 100 to 50 $\mathrm{ms}$ further reduced the observed response $(2.3 \pm 0.5 \mathrm{mv}, n=7$, naive, $100 \mu \mathrm{M}$ ACh; Fig. $5 D$, gray), although it remained depolarizing. Accordingly, $100 \mu \mathrm{M}$ ACh applications (100 ms) effectively increased the firing frequency of L5 pyramidal neurons, causing a leftward shift in the I/O curve (Fig. $5 E$ ) similar to that caused by $1 \mathrm{~mm}$ ACh.

\section{ACh-evoked current is mediated by the M1 receptor}

In the brain, ACh can activate two types of receptors: ionotropic nicotinic and metabotropic muscarinic receptors, which mediate currents with very different properties (McCormick and Prince, 1985; Nathanson, 1987; McGehee and Role, 1995). The nature of the slow-activating, long-lasting inward current in mPFC pyramidal neurons is still controversial because it was previously suggested to depend on the closure of G-protein-coupled potassium channels (Carr and Surmeier, 2007), the opening of muscarinic receptor-coupled cationic channels (Haj-Dahmane and Andrade, 1996; Kurowski et al., 2015), or the activation of $\alpha 4 \beta 2$ subunit-containing nicotinic receptors (Guillem et al., 2011). We designed voltage-clamp experiments to determine the properties of the ACh-induced depolarizing current in L5 pyramidal cells of sham and SNI animals; for these recordings, we maximized the neuronal response to ACh by using $1 \mathrm{~mm}$ ACh focally applied for $100 \mathrm{~ms}$. In addition, because the hyperpolarizing component of the evoked response was completely blocked when the intracellular solution contained Cs, we isolated the depolarizing compo- nent by using a Cs-methanesulfonate-based intrapipette solution. Bath application of ACh $(1 \mathrm{~mm}$, at $-70 \mathrm{mV})$ elicited a slow, inward current in sham and SNI animals (Fig. 6A). Consistent with our current-clamp results, the inward current recorded in neurons from SNI animals was smaller compared with sham $(-36.5 \pm 5.2 \mathrm{pA}$ vs $-89.5 \pm 9.6 \mathrm{pA}$, respectively, 10 cells in each group; $p=0.0003$; Fig. $6 B$ ). The magnitude of the reduction was similar when the current was normalized to cell capacitance $(0.25 \pm 0.03$ vs $0.65 \pm 0.09 \mathrm{pA} / \mathrm{pF}$, respectively; $p=0.001)$, thereby ruling out the possibility that the reduction was simply due differences in cell size (Kelly et al., 2016). Eliciting the current with short, focal somatic ACh applications yielded results similar to those obtained with bath application (Fig. 6C,D). We then used a pharmacological approach to identify the type of cholinergic receptor involved. After applying ACh ( $1 \mathrm{~mm}$ ) focally for $100 \mathrm{~ms}$ and recording a control response, we bath applied the nonspecific muscarinic ACh receptor antagonist atropine (2 $\mu \mathrm{M})$. When the bath solution was completely exchanged, we reapplied the ACh and measured the response. Atropine blocked $96.3 \pm 2.2 \%$ of the ACh-evoked current in sham and $89.2 \pm 8.6 \%$ in SNI animals (Fig. 7A, $B$ ), showing that activation of a muscarinic receptor mediates the response in both experimental groups. We further identified the nature of the receptor involved by testing the effect of the M1 muscarinic receptor antagonist pirenzepine (Hammer et al., 1980) and the M2 antagonist methoctramine (Gulledge and Kawaguchi, 2007). Because the sensitivity to atropine was the same in sham and SNI, these recordings were only performed in slices from sham or naive rats, in which the larger currents allow more reliable quantification of the drug effects. We found that pirenzepine at either $10 \mu \mathrm{M}$ $(93.5 \pm 5.6 \%$ block $n=5$, sham $)$ or $2 \mu \mathrm{M}(82.03 \pm 13.2 \%$ block, $n=3$, naive; Fig. $7 C, D)$ produced a current block similar to that by atropine, showing that the cholinergic inward current is al- 
A

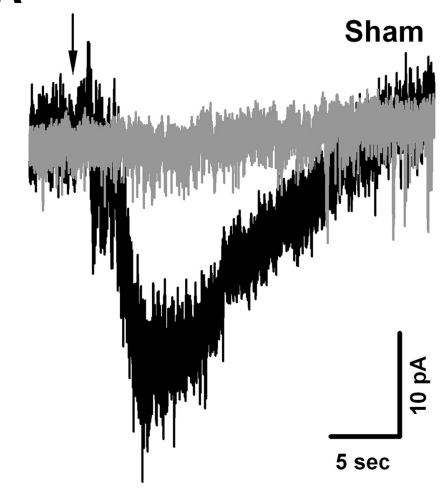

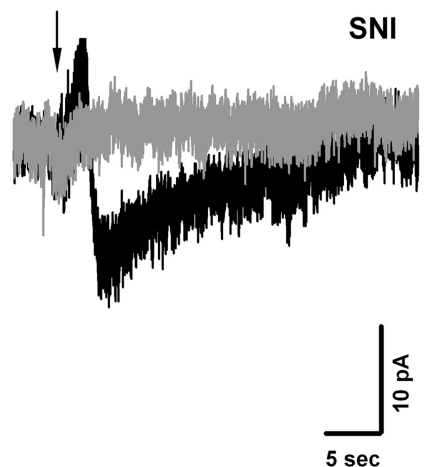

D

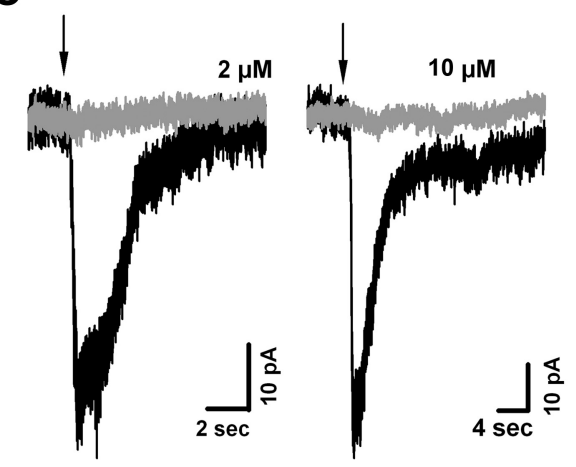

B

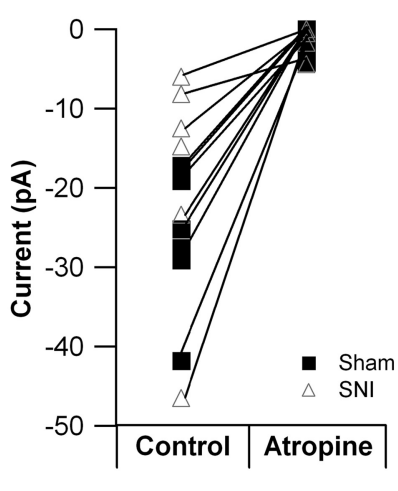

$\mathbf{E}$

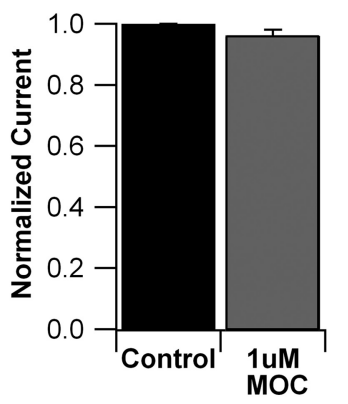

Figure 7. Depolarizing cholinergic current in $\mathrm{mPFC}$ neurons is mediated by the M1 receptor. $A$, Traces represent peak current responses to focal application of $1 \mathrm{~mm}$ ACh (arrow) in control conditions (black) and in the presence of $2 \mu \mathrm{m}$ bath-applied atropine (gray) in a mPFC neuron from sham (left) and SNI (right) animals. Voltage was $-70 \mathrm{mV}$. B, Atropine blocked the ACh-activated current (the block of the peak current was $96.32 \pm 2.17 \%$ in sham and $89.2 \pm 8.6 \%$ in SNI animals ( $n=6$ for each group). C, Current responses to $1 \mathrm{~mm}$ focally applied ACh (arrow) in control conditions (black) and after bath application of either $2 \mu \mathrm{m}$ pirenzepine (gray) or $10 \mu \mathrm{m}$ pirenzepine (gray). D, Summary of the effect of either 2 or $10 \mu \mathrm{m}$ pirenzepine on the ACh-elicited current. Ten micromolar pirenzepine blocked $93.54 \pm 5.62 \%$ ( $p=0.002 ; 5$, cells from sham animals) of the current. Similarly, $2 \mu \mathrm{m}$ pirenzepine blocked $82.03 \pm 13.21 \%$ ( $p=0.01 ; n=3$, naive animals) of the peak control current. $\boldsymbol{E}$, Depolarizing current evoked by ACh (1 mM) was not affected by bath application of the M2 blocker methoctramine ( $1 \mu \mathrm{m}$; the current was $96 \pm 0.02 \%$ of that in control; $n=5$ cells from naive animals).

most completely mediated by M1-subunit-containing muscarinic receptors. Consistent with these data, the M2 antagonist methoctramine did not produce any detectable effect on the current (the ACh response after 5 min of bath-applied $1 \mu \mathrm{M}$ methoctramine was $96 \pm 0.02 \%$ of control, $n=5$ cells; Fig. $7 E$ ).

What is the mechanism mediating the reduction of the depolarizing muscarinic current in SNI animals?

Muscarinic receptors are expressed throughout the cortex and may be coupled to diverse ion channels through G-protein- and calcium-dependent biochemical cascades. In the hippocampus, activation of muscarinic receptors of CA1 pyramidal neurons results in a net depolarizing response thought to be mediated by the inhibition of potassium currents, specifically the M-current, as well as by activation of cationic currents (Halliwell and Adams, 1982; Fisahn et al., 2002). Similar heterogeneity has been reported in cortical pyramidal neurons. In our preparation, the depolarizing response was not mediated by potassium channels because it persisted when using a Cs-based pipette solution and when the extracellular solution contained barium $(0.5 \mathrm{mM}$, data not shown; 3 cells). This finding is consistent with previous reports suggesting that the muscarinic current in the same brain area is mediated by nonspecific cationic channels (Haj-Dahmane and Andrade, 1997; Lei et al., 2014). The precise identity of the subunits mediating this current in L5 of the PL cortex is still unclear. Yan et al. (2009) showed that the expression level of TRPC5 and TRPC6 subunits modulates the current mediating the sADP in L3-5 pyramidal neurons of the mPFC, whereas Zhang et al. (2011) suggested that TRPC4/5 subunits are critical mediators of the cholinergic plateau potentials in the entorhinal cortex. Lei et al. (2014) examined the subunit composition of the muscarinic sADP in L5 pyramidal neurons of the mouse mPFC, the same area as our study, and concluded that it is largely mediated by TRPM 5 and TRPM4 subunits. More recently, Kurowski et al. (2015) reported that, in L5 mPFC neurons of young (18-22 d) rats, M1 muscarinic receptors are coupled to Nav1.9 channels that mediate a sustained depolarizing current, similar to the one described here. Therefore, multiple channels appear to be coupled to the M1 receptor in these cells, with TRPM channels likely involved in the sADP and Nav1.9 in the persistent depolarizing response. To identify the mechanism causing the loss of cholinergic modulation, we used qRT-PCR to determine the expression levels of the M1 muscarinic receptor, TRPC4, TRPC5, TRPC6 TRPM4, TRPM5, and Nav1.9, the subunits most likely to mediate the coupled currents, in L5 of the rat mPFC. In addition, because an increase in acetylcholinesterase may reduce $\mathrm{ACh}$ availability and thus cause a decrease in muscarinic current, we also studied the expression of this transcript. We found that M1, TRPC4, TRPC5, TRPC6, TRPM4, Nav1.9, and acetylcholinesterase were all expressed, whereas TRPM5 did not produce a signal 

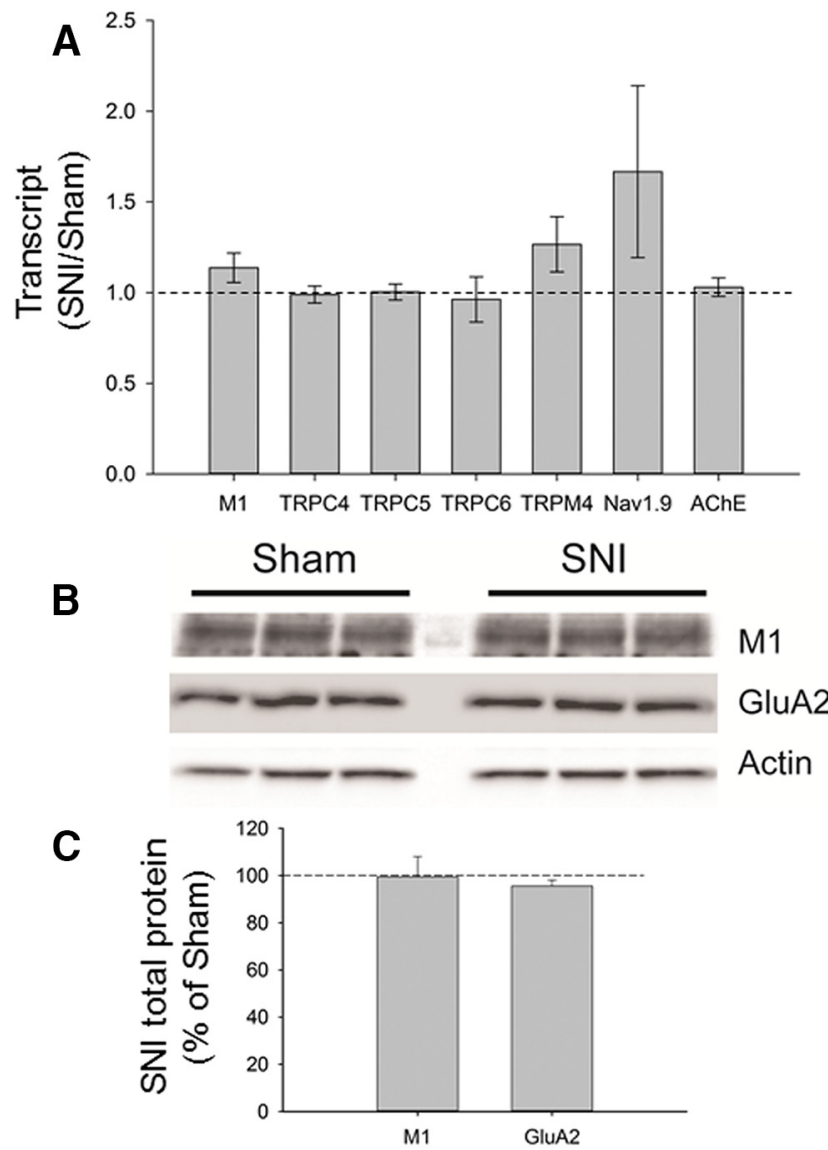

Figure 8. Level of $M 1 \mathrm{mRNA}$ and total protein is unaffected in $\mathrm{L} 5 \mathrm{mPFC}$ of $S \mathrm{~N} I$ rats. $A, \mathrm{qRT}-\mathrm{PCR}$ was performed on CDNA from tissue isolated from $L 5$ of the $\mathrm{MPFC}$ contralateral to the surgery site to measure the expression of several transcripts potentially involved in the reduction of cholinergic modulation in SNI animals. No significant decrease was observed for any of the transcripts investigated. $\boldsymbol{B}$, Representative blots showing the total expression of $\mathrm{M} 1$ and the AMPAR subunit GluA2 protein in L5 mPFC of sham and SNI animals. C, Total amount of protein in mPFC L 5 of SNI rats normalized to actin and compared with expression level in sham (dotted line); similar to the PCR data, no difference was found in M1 expression in SNI relative to sham.

above the background. Next, we investigated whether an altered expression of any of these transcripts may account for the current reduction in SNI animals by comparing their expression levels in L5 of the $\mathrm{mPFC}$ contralateral to the peripheral lesion. Similar to the electrophysiological recordings, this analysis was performed 1 week after SNI/sham surgery. Compared with sham, no significant change in transcript level of any of these target genes was detected in the $\mathrm{mPFC}$ tissue obtained from SNI rat brains (contralateral to surgery, 14 sham and 16 SNI rats; Fig. $8 A$ ). Therefore, the smaller current amplitude in SNI is unlikely to be caused by a reduction of either M1 or the potentially coupled candidate channel transcripts. Finally, we confirmed by immunoblotting that SNI surgery does not modify the total $\mathrm{M} 1$ protein level in $\mathrm{L} 5 \mathrm{mPFC}$ (contralateral to surgery) from sham and SNI rats (Fig. $8 B, C$ ).

Both ligand-gated channels and G-protein-coupled receptors can be strongly modulated through mechanisms of desensitization and trafficking. In the case of muscarinic receptors, this modulation can lead to clathrin-mediated endocytosis of the receptor and eventual degradation (Tsuga et al., 1998). Biochemical techniques can be used to measure what fraction of a protein is bound to the plasma membrane and what fraction is associated with internal membranes. Therefore, we first collected L5 mPFC tissue (contralateral to peripheral injury site) from sham and SNI rats 1 week after surgery and performed a subcellular fractionation protocol to isolate the SPM fraction, followed by Western blot analysis using an M1 antibody. Once more, the total amount of M1 protein in mPFC L5 was unaffected by SNI surgery (Fig. $9 A, B)$; the fraction bound to the plasma membrane, however, was significantly reduced in tissue from SNI rats (the SPM/homogenate fraction in SNI was $81.2 \pm 5.3 \%$ of that in sham; 7 groups each, 3 hemispheres per group; Fig. $9 A, B)$. To further support this mechanistic interpretation, we performed surface biotinylation in acute mPFC slices from a different group of rats (12 sham and 12 SNI). In agreement with the fractionation data, we found that the surface expression level of M1 in isolated contralateral mPFC L5 tissue (fraction biotinylated and recovered with NeutrAvidin beads) was significantly reduced in SNI rats $(83.5 \pm 2.1 \%$ of that in sham; Fig. $9 C, D)$. As a control for our fractionation and biotinylation experiments, we analyzed the surface expression level of the AMPA subunit GluA2, which was not affected by SNI surgery. Therefore, our results strongly suggest that the reduction in muscarinic current in the contralateral $\mathrm{PL} \mathrm{mPFC}$ of SNI animals is due, at least in part, to M1 receptor internalization.

\section{Discussion}

Our data show that, 1 week after the onset of peripheral neuropathy (SNI model), cholinergic modulation is dramatically reduced in L5 pyramidal neurons of the contralateral PL cortex of SNI animals. We demonstrate that a cationic current apparently mediated by M1 receptor activation is reduced in L5 pyramidal neurons from SNI animals. The muscarinic nature of the cholinergic depolarizing response in these cells is consistent with a recent study (Hedrick and Waters, 2015) showing that L5 pyramidal neurons of the mPFC almost completely lack nicotinic responses. The downregulation of this muscarinic current virtually eliminates the ability of ACh to increase intrinsic neuronal excitability and to induce sustained firing. Although we observed no changes in the gene expression of any of the cationic channels potentially coupled to the M1 receptor, we found a significant reduction in the plasma-membrane-bound fraction of M1 protein in SNI animals a mere $7 \mathrm{~d}$ after surgery. This finding suggests that $\mathrm{M} 1$ receptor internalization may mediate this functional impairment, although the apparent disproportion between the large functional effect and the change $(\sim 20 \%)$ in M1 surface expression suggests that other mechanisms are also likely to be involved. Finally, we propose that the impairment in cholinergic modulation contributes to the general functional mPFC deactivation associated with chronic neuropathic pain (Ji and Neugebauer, 2011; Lee et al., 2015; Zhang et al., 2015).

\section{Disruption of cholinergic signaling in the mPFC may underlie higher-level cognitive impairment associated with neuropathic pain}

Recent studies support the idea that chronic pain is associated with major reorganization of the nervous system. This includes nociceptors and the spinal cord (Woolf and Salter, 2000; Sandkühler, 2009), but also many supraspinal structures. In the SNI model, synaptic transmission is potentiated in the anterior cingulate cortex as early as 1 week after the neuropathic lesion (Xu et al., 2008) and functional and morphological changes are found throughout the limbic system (Metz et al., 2009; Mutso et al., 2012; Chang et al., 2014), with the PFC appearing to be particularly involved. Functional imaging studies show hypoactivity (Gündel et al., 2008) and decreased levels of excitatory neurotransmitters (Grachev and Apkarian, 2001) in the mPFC of 
A

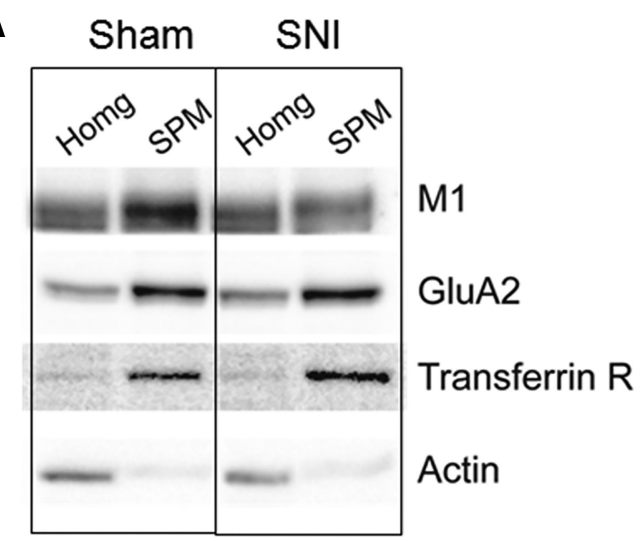

C

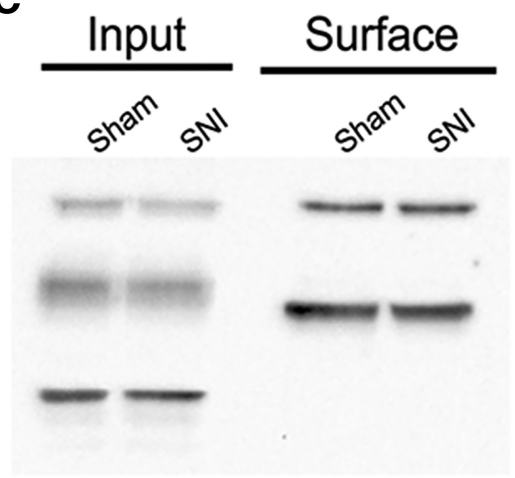

B

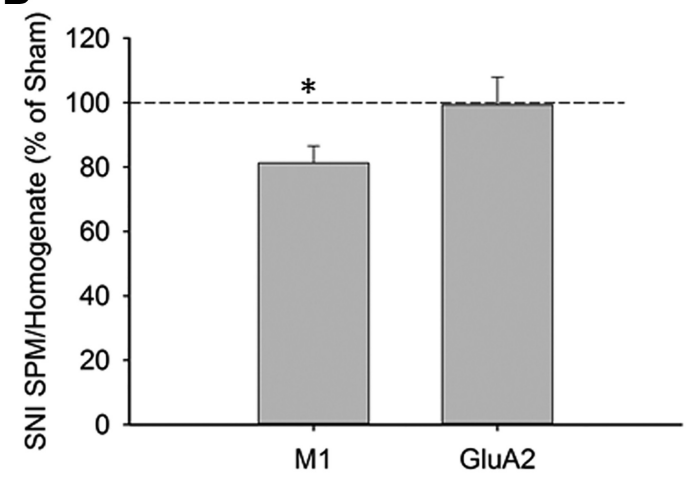

$\mathbf{D}$

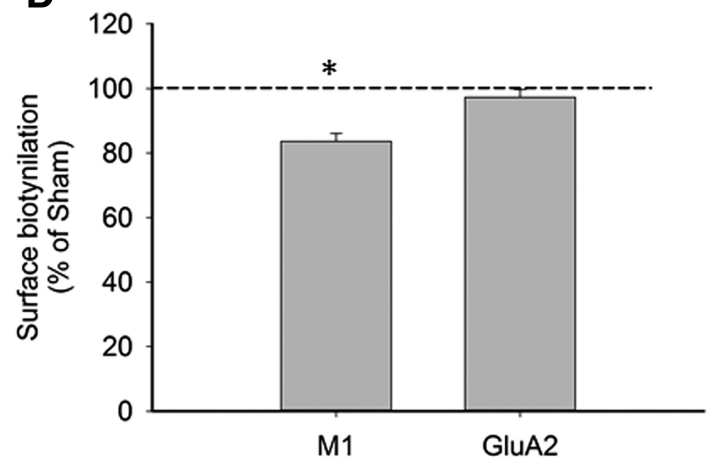

Figure 9. Surface expression of M1 muscarinic receptor is reduced in L5 mPFC of SNI animals. Representative blots (A) showing the total expression (Homg) and fraction associated with SPM of the indicated proteins in L5 mPFC. $\boldsymbol{B}$, Bar chart showing the significant decrease of M1 receptor in the SPM fraction ( $81.2 \pm 5.3 \%$ of sham level; $n=7$ and 7,3 animals per sample, $p=0.017)$. $\boldsymbol{C}$, Slice biotinylation experiment showing the total (Input) and surface expressed (Surface) fraction of the indicated proteins. The cytosolic protein actin was evaluated as a control. $\boldsymbol{D}$, Quantification of the data in C showing a significant reduction in the levels of surface-expressed M1 receptor in SNI rats ( $83.5 \pm 2.1 \%$ of sham level; 4 samples in each condition, 3 animals per sample, $p=0.029)$.

chronic pain patients. Similar cortical deactivation is also observed in animal studies, in which the pain-associated mPFC inhibition is thought to be driven by hyperactivity of the amygdalar inputs to the $\mathrm{mPFC}$, which results in a group 1 metabotropic glutamate receptor-mediated increase in local GABAergic activity (Ji et al., 2010; Ji and Neugebauer, 2011). Our data support this general picture and add an important piece of evidence by showing that, 1 week after neuropathic injury, ACh-evoked intrinsic excitability of L5 pyramidal neurons was dramatically decreased in SNI animals due to the loss of muscarinic modulation, further supporting the idea of a pain-associated deactivation of this brain area soon after neuropathic injury.

Even more importantly, because of the well established role of cholinergic signaling in attention and memory processes (Hasselmo and Sarter, 2011; Zhou et al., 2011; Yoshida et al., 2012), it is tempting to hypothesize that the loss of cholinergic signaling has a causal role in the deficits in attention and working memory that have been reported in human patients and in animal models of neuropathic pain. Patients with chronic pain show impaired decision making and disrupted attention and working memory (Apkarian et al., 2004; Dick and Rashiq, 2007). Attentional processing is thought to involve the integration of multiple modes of input within a discrete temporal window. In the $\mathrm{mPFC}$, pyramidal neurons of L5 receive glutamatergic, sensory input from the thalamus in parallel with cue-specific, cholinergic input from nucleus basalis (Parikh et al., 2007). Successful cue detection, which requires ACh release in the $\mathrm{MPFC}$ and is sensitive to muscarinic receptor antagonism, is adversely affected in a rodent model of chronic pain (Pais-Vieira et al., 2009a). Interestingly, these deficits persist even when the hypersensitive peripheral areas and acute pain responses are mitigated by lidocaine, further emphasizing the role of supraspinal reorganization. Because previous work showed that a cholinergic nonspecific cationic current is critical for the persistent firing that is believed to serve as a memory trace in neurons of the temporal lobe (Yoshida et al., 2012), the reduced muscarinic response and the lack of an AChdependent modulation of the I/O curve that we observed in SNI animals could result in the missing of relevant cues and the ultimate disruption of mPFC-dependent attentional processing. Consistent with this hypothesis, the persistent "reverberant" firing that we found in sham animals, in which neurons continue to fire for tens of seconds after a brief application of ACh, was virtually nonexistent in SNI animals. Therefore, the reduced muscarinic current and loss of ACh-evoked persistent firing in SNI rats may represent the cellular background for the cognitive deficits associated with chronic pain. This scenario is consistent with the known impairment of working memory by pharmacological antagonism of muscarinic receptors (Zhou et al., 2011).

\section{Is the loss of cortical muscarinic modulation causal for pain chronification?}

It was reported recently that direct optogenetic activation of the mPFC output reduces allodynia in SNI animals (Lee et al., 2015). Similar results were obtained by optogenetic inhibition of $\mathrm{mPFC}$ GABAergic neurons (Zhang et al., 2015). These findings support the idea that, in the pain state, the mPFC is functionally deactivated and match the observation that, in a rodent model of arthritis, enhanced amygdalar inputs inhibit mPFC pyramidal neurons through activa- 
tion of interneurons (Ji et al., 2010). Intriguingly, according to their firing pattern, the cells investigated in this study are commissurally projecting neurons; therefore, the impaired cholinergic modulation that decreases the contralateral excitability may also contribute to the decreased glutamatergic tone (Kelly et al., 2016). Therefore, in the pain condition, different synergistic network activity modulations lead to cortical deactivation that modulates the allodynia. The impaired cholinergic modulation described here provides another mechanism contributing to the overall deactivation of the mPFC. This deactivation, however, is part of a larger and more complex reorganization that involves the entire limbic system. At an early time point ( $\sim 1$ week after injury), the extent of the reorganization is astoundingly large. It involves impaired plasticity in the hippocampus (Ren et al., 2011; Mutso et al., 2012), increased intrinsic excitability of indirect pathway spiny neurons of the nucleus accumbens shell (Ren et al., 2016), increased amygdala activation (Ji et al., 2010), and decreased glutamatergic tone in the mPFC (Kelly et al., 2016). Although this is a very complex picture, and one that is likely to change at later time points (Ren et al., 2011; Chang et al., 2014), it depicts a relatively consistent scenario in which the negative valence limbic system (amygdala-mPFC) is enhanced. It is interesting that systemic administration of donepezil, an acetylcholinesterase inhibitor, was reported to decrease allodynia in SNI rats, although apparently through an M2-dependent mechanism and at a later time point (Ferrier et al., 2015).

Therefore, the picture that emerges is complex and evolving. To further complicate matters, we have to keep in mind that, even at this early time point, whereas the sign of the mPFC activity related to pain is clear at the system level (deactivation of the PL output), this is likely the result of multiple cellular mechanisms. For example, L2/3 pyramidal neurons of the mPFC appear to receive increased excitatory input in pain conditions (Metz et al., 2009; Wang et al., 2015), but this is counterbalanced by decreased intrinsic excitability that leads to the inability of these neurons to generate action potentials and to cortical deactivation despite increased inputs (Wang et al., 2015). Similarly, different cortical layers and individual pyramidal cells within a single layer may be differentially regulated (e.g., dendritic complexity of L5 pyramidal cells of SNI animals is decreased in L3-4, but not in L1-2 or L6 (Kelly et al., 2016)) and the role of the many inhibitory interneurons may further complicate the picture. Therefore, this represents a typical example in which a relatively well defined functional fingerprint at the macroscopic (organ) level, such as that resolvable with fMRI studies, appears to be the result of a myriad of complex and possibly contrasting events at the cellular/molecular level.

\section{References}

Apkarian AV, Sosa Y, Krauss BR, Thomas PS, Fredrickson BE, Levy RE, Harden RN, Chialvo DR (2004) Chronic pain patients are impaired on an emotional decision-making task. Pain 108:129-136. CrossRef Medline

Arnsten AF, Rubia K (2012) Neurobiological circuits regulating attention, cognitive control, motivation, and emotion: disruptions in neurodevelopmental psychiatric disorders. J Am Acad Child Adolesc Psychiatry 51: 356-367. CrossRef Medline

Arroyo S, Bennett C, Hestrin S (2014) Nicotinic modulation of cortical circuits. Front Neural Circuits 8:30. CrossRef Medline

Baker KS, Gibson S, Georgiou-Karistianis N, Roth RM, Giummarra MJ (2016) Everyday executive functioning in chronic pain: specific deficits in working memory and emotion control, predicted by mood, medications, and pain interference. Clin J Pain 32:673-680. CrossRef Medline

Bustin SA, Beaulieu JF, Huggett J, Jaggi R, Kibenge FS, Olsvik PA, Penning LC, Toegel S (2010) MIQE precis: Practical implementation of minimum standard guidelines for fluorescence-based quantitative real-time PCR experiments. BMC Mol Biol 11:74. CrossRef Medline
Carr DB, Surmeier DJ (2007) M1 muscarinic receptor modulation of Kir2 channels enhances temporal summation of excitatory synaptic potentials in prefrontal cortex pyramidal neurons. J Neurophysiol 97:3432-3438. CrossRef Medline

Chang PC, Pollema-Mays SL, Centeno MV, Procissi D, Contini M, Baria AT, Martina M, Apkarian AV (2014) Role of nucleus accumbens in neuropathic pain: linked multi-scale evidence in the rat transitioning to neuropathic pain. Pain 155:1128-1139. CrossRef Medline

Chapman V, Suzuki R, Dickenson AH (1998) Electrophysiological characterization of spinal neuronal response properties in anaesthetized rats after ligation of spinal nerves L5-L6. J Physiol 507:881-894. CrossRef Medline

Croxson PL, Kyriazis DA, Baxter MG (2011) Cholinergic modulation of a specific memory function of prefrontal cortex. Nat Neurosci 14:1510 1512. CrossRef Medline

Decosterd I, Woolf CJ (2000) Spared nerve injury: an animal model of persistent peripheral neuropathic pain. Pain 87:149-158. CrossRef Medline

Dembrow NC, Chitwood RA, Johnston D (2010) Projection-specific neuromodulation of medial prefrontal cortex neurons. J Neurosci 30:1692216937. CrossRef Medline

Dick BD, Rashiq S (2007) Disruption of attention and working memory traces in individuals with chronic pain. Anesth Analg 104:1223-1229, tables of contents. CrossRef Medline

Ferrier J, Bayet-Robert M, Dalmann R, El Guerrab A, Aissouni Y, GraveronDemilly D, Chalus M, Pinguet J, Eschalier A, Richard D, Daulhac L, Marchand F, Balayssac D (2015) Cholinergic neurotransmission in the posterior insular cortex is altered in preclinical models of neuropathic pain: key role of muscarinic M2 receptors in donepezil-induced antinociception. J Neurosci 35:16418-16430. CrossRef Medline

Fisahn A, Yamada M, Duttaroy A, Gan JW, Deng CX, McBain CJ, Wess J (2002) Muscarinic induction of hippocampal gamma oscillations requires coupling of the $\mathrm{M} 1$ receptor to two mixed cation currents. Neuron 33:615-624. CrossRef Medline

Goldman-Rakic PS (1995) Cellular basis of working memory. Neuron 14: 477-485. CrossRef Medline

Grachev ID, Apkarian AV (2001) Chemical network of the living human brain: evidence of reorganization with aging. Brain Res Cogn Brain Res 11:185-197. CrossRef Medline

Granon S, Poucet B, Thinus-Blanc C, Changeux JP, Vidal C (1995) Nicotinic and muscarinic receptors in the rat prefrontal cortex: differential roles in working memory, response selection and effortful processing. Psychopharmacology 119:139-144. CrossRef Medline

Guillem K, Bloem B, Poorthuis RB, Loos M, Smit AB, Maskos U, Spijker S, Mansvelder HD (2011) Nicotinic acetylcholine receptor beta2 subunits in the medial prefrontal cortex control attention. Science 333:888-891. CrossRef Medline

Gulledge AT, Kawaguchi Y (2007) Phasic cholinergic signaling in the hippocampus: functional homology with the neocortex? Hippocampus 17: 327-332. CrossRef Medline

Gündel H, Valet M, Sorg C, Huber D, Zimmer C, Sprenger T, Tolle TR (2008) Altered cerebral response to noxious heat stimulation in patients with somatoform pain disorder. Pain 137:413-421. CrossRef Medline

Haj-Dahmane S, Andrade R (1996) Muscarinic activation of a voltagedependent cation nonselective current in rat association cortex. J Neurosci 16:3848-3861. Medline

Haj-Dahmane S, Andrade R (1997) Calcium-activated cation nonselective current contributes to the fast afterdepolarization in rat prefrontal cortex neurons. J Neurophysiol 78:1983-1989. Medline

Haj-Dahmane S, Andrade R (1999) Muscarinic receptors regulate two different calcium-dependent non-selective cation currents in rat prefrontal cortex. Eur J Neurosci 11:1973-1980. CrossRef Medline

Hallett PJ, Collins TL, Standaert DG, Dunah AW (2008) Biochemical fractionation of brain tissue for studies of receptor distribution and trafficking. Curr Protoc Neurosci Chapter 1:Unit 1.16. CrossRef Medline

Halliwell JV, Adams PR (1982) Voltage-clamp analysis of muscarinic excitation in hippocampal neurons. Brain Res 250:71-92. CrossRef Medline

Hammer R, Berrie CP, Birdsall NJ, Burgen AS, Hulme EC (1980) Pirenzepine distinguishes between different subclasses of muscarinic receptors. Nature 283:90-92. CrossRef Medline

Hasselmo ME, Sarter M (2011) Modes and models of forebrain cholinergic neuromodulation of cognition. Neuropsychopharmacology 36:52-73. CrossRef Medline 
Hedrick T, Waters J (2015) Acetylcholine excites neocortical pyramidal neurons via nicotinic receptors. J Neurophysiol 113:2195-2209. CrossRef Medline

Jay TM, Glowinski J, Thierry AM (1989) Selectivity of the hippocampal projection to the prelimbic area of the prefrontal cortex in the rat. Brain Res 505:337-340. CrossRef Medline

Ji G, Neugebauer V (2011) Pain-related deactivation of medial prefrontal cortical neurons involves mGluR1 and GABA(A) receptors. J Neurophysiol 106:2642-2652. CrossRef Medline

Ji G, Sun H, Fu Y, Li Z, Pais-Vieira M, Galhardo V, Neugebauer V (2010) Cognitive impairment in pain through amygdala-driven prefrontal cortical deactivation. J Neurosci 30:5451-5464. CrossRef Medline

Jung MW, Qin Y, McNaughton BL, Barnes CA (1998) Firing characteristics of deep layer neurons in prefrontal cortex in rats performing spatial working memory tasks. Cereb Cortex 8:437-450. CrossRef Medline

Kelly CJ, Huang M, Meltzer H, Martina M (2016) Reduced glutamatergic currents and dendritic branching of layer 5 pyramidal cells contribute to medial prefrontal cortex deactivation in a rat model of neuropathic pain. Front Cell Neurosci 10:133. CrossRef Medline

Klinkenberg I, Blokland A (2011) A comparison of scopolamine and biperiden as a rodent model for cholinergic cognitive impairment. Psychopharmacology 215:549-566. CrossRef Medline

Krettek JE, Price JL (1977) Projections from the amygdaloid complex to the cereb cortex and thalamus in the rat and cat. J Comp Neurol 172:687-722. CrossRef Medline

Kurowski P, Gawlak M, Szulczyk P (2015) Muscarinic receptor control of pyramidal neuron membrane potential in the medial prefrontal cortex (mPFC) in rats. Neuroscience 303:474-488. CrossRef Medline

Lee M, Manders TR, Eberle SE, Su C, D’Amour J, Yang R, Lin HY, Deisseroth K, Froemke RC, Wang J (2015) Activation of corticostriatal circuitry relieves chronic neuropathic pain. J Neurosci 35:5247-5259. CrossRef Medline

Lei YT, Thuault SJ, Launay P, Margolskee RF, Kandel ER, Siegelbaum SA (2014) Differential contribution of TRPM4 and TRPM5 nonselective cation channels to the slow afterdepolarization in mouse prefrontal cortex neurons. Front Cell Neurosci 8:267. CrossRef Medline

Livak KJ, Schmittgen TD (2001) Analysis of relative gene expression data using real-time quantitative PCR and the 2(-Delta Delta C(T)) method. Methods 25:402-408. CrossRef Medline

Mansvelder HD, van Aerde KI, Couey JJ, Brussaard AB (2006) Nicotinic modulation of neuronal networks: from receptors to cognition. Psychopharmacology 184:292-305. CrossRef Medline

McCormick DA, Prince DA (1985) Two types of muscarinic response to acetylcholine in mammalian cortical neurons. Proc Natl Acad Sci U S A 82:6344-6348. CrossRef Medline

McGehee DS, Role LW (1995) Physiological diversity of nicotinic acetylcholine receptors expressed by vertebrate neurons. Annu Rev Physiol 57:521-546. Medline

McQuiston AR, Madison DV (1999) Muscarinic receptor activity induces an afterdepolarization in a subpopulation of hippocampal CA1 interneurons. J Neurosci 19:5703-5710. Medline

Mesulam MM, Mufson EJ, Wainer BH, Levey AI (1983) Central cholinergic pathways in the rat: an overview based on an alternative nomenclature (Ch1-Ch6). Neuroscience 10:1185-1201. CrossRef Medline

Metz AE, Yau HJ, Centeno MV, Apkarian AV, Martina M (2009) Morphological and functional reorganization of rat medial prefrontal cortex in neuropathic pain. Proc Natl Acad Sci U S A 106:2423-2428. CrossRef Medline

Moriarty O, McGuire BE, Finn DP (2011) The effect of pain on cognitive function: a review of clinical and preclinical research. Prog Neurobiol 93:385-404. CrossRef Medline

Mutso AA, Radzicki D, Baliki MN, Huang L, Banisadr G, Centeno MV, Radulovic J, Martina M, Miller RJ, Apkarian AV (2012) Abnormalities in hippocampal functioning with persistent pain. J Neurosci 32:5747-5756. CrossRef Medline

Nathanson NM (1987) Molecular properties of the muscarinic acetylcholine receptor. Annu Rev Neurosci 10:195-236. Medline

Neugebauer V, Galhardo V, Maione S, Mackey SC (2009) Forebrain pain mechanisms. Brain Res Rev 60:226-242. CrossRef Medline

Pais-Vieira M, Lima D, Galhardo V (2009a) Sustained attention deficits in rats with chronic inflammatory pain. Neurosci Lett 463:98-102. CrossRef Medline

Pais-Vieira M, Mendes-Pinto MM, Lima D, Galhardo V (2009b) Cognitive impairment of prefrontal-dependent decision-making in rats after the onset of chronic pain. Neuroscience 161:671-679. CrossRef Medline
Parent MA, Wang L, Su J, Netoff T, Yuan LL (2010) Identification of the hippocampal input to medial prefrontal cortex in vitro. Cereb Cortex 20:393-403. CrossRef Medline

Parikh V, Kozak R, Martinez V, Sarter M (2007) Prefrontal acetylcholine release controls cue detection on multiple timescales. Neuron 56:141154. CrossRef Medline

Paxinos G, Watson C (1998) The rat brain in stereotaxic coordinates, Ed 4. New York: Academic.

Ren WJ, Liu Y, Zhou LJ, Li W, Zhong Y, Pang RP, Xin WJ, Wei XH, Wang J, Zhu HQ, Wu CY, Qin ZH, Liu G, Liu XG (2011) Peripheral nerve injury leads to working memory deficits and dysfunction of the hippocampus by upregulation of TNF-alpha in rodents. Neuropsychopharmacology 36: 979-992. CrossRef Medline

Ren W, Centeno MV, Berger S, Wu Y, Na X, Liu X, Kondapalli J, Apkarian AV, Martina M, Surmeier DJ (2016) The indirect pathway of the nucleus accumbens shell amplifies neuropathic pain. Nat Neurosci 19:220222. CrossRef Medline

Romanides AJ, Duffy P, Kalivas PW (1999) Glutamatergic and dopaminergic afferents to the prefrontal cortex regulate spatial working memory in rats. Neuroscience 92:97-106. CrossRef Medline

Sandkühler J (2009) Models and mechanisms of hyperalgesia and allodynia. Physiol Rev 89:707-758. CrossRef Medline

Sanz-Clemente A, Matta JA, Isaac JT, Roche KW (2010) Casein kinase 2 regulates the NR2 subunit composition of synaptic NMDA receptors. Neuron 67:984-996. CrossRef Medline

Sarter M, Bruno JP (1997) Cognitive functions of cortical acetylcholine: toward a unifying hypothesis. Brain Res Brain Res Rev 23:28-46. CrossRef Medline

Satake T, Mitani H, Nakagome K, Kaneko K (2008) Individual and additive effects of neuromodulators on the slow components of afterhyperpolarization currents in layer $\mathrm{V}$ pyramidal cells of the rat medial prefrontal cortex. Brain Res 1229:47-60. CrossRef Medline

Schmittgen TD, Livak KJ (2008) Analyzing real-time PCR data by the comparative $C(T)$ method. Nat Protoc 3:1101-1108. CrossRef Medline

Tsuga H, Kameyama K, Haga T (1998) Desensitization of human muscarinic acetylcholine receptor $\mathrm{m} 2$ subtypes is caused by their sequestration/ internalization. J Biochem 124:863-868. CrossRef Medline

Vertes RP (2006) Interactions among the medial prefrontal cortex, hippocampus and midline thalamus in emotional and cognitive processing in the rat. Neuroscience 142:1-20. CrossRef Medline

Vertes RP, Hoover WB, Szigeti-Buck K, Leranth C (2007) Nucleus reuniens of the midline thalamus: link between the medial prefrontal cortex and the hippocampus. Brain Res Bull 71:601-609. CrossRef Medline

Vidal C, Changeux JP (1993) Nicotinic and muscarinic modulations of excitatory synaptic transmission in the rat prefrontal cortex in vitro. Neuroscience 56:23-32. CrossRef Medline

Wang ZT, Yu G, Wang HS, Yi SP, Su RB, Gong ZH (2015) Changes in VGLUT2 expression and function in pain-related supraspinal regions correlate with the pathogenesis of neuropathic pain in a mouse spared nerve injury model. Brain Res 1624:515-524. CrossRef Medline

Woolf CJ, Salter MW (2000) Neuronal plasticity: increasing the gain in pain. Science 288:1765-1769. CrossRef Medline

Xu H, Wu LJ, Wang H, Zhang X, Vadakkan KI, Kim SS, Steenland HW, Zhuo M (2008) Presynaptic and postsynaptic amplifications of neuropathic pain in the anterior cingulate cortex. J Neurosci 28:7445-7453. CrossRef Medline

Yan HD, Villalobos C, Andrade R (2009) TRPC channels mediate a muscarinic receptor-induced afterdepolarization in cerebral cortex. J Neurosci 29:10038-10046. CrossRef Medline

Yoshida M, Knauer B, Jochems A (2012) Cholinergic modulation of the CAN current may adjust neural dynamics for active memory maintenance, spatial navigation and time-compressed replay. Front Neural Circuits 6:10. CrossRef Medline

Zhang Z, Reboreda A, Alonso A, Barker PA, Séguéla P (2011) TRPC channels underlie cholinergic plateau potentials and persistent activity in entorhinal cortex. Hippocampus 21:386-397. CrossRef Medline

Zhang Z, Gadotti VM, Chen L, Souza IA, Stemkowski PL, Zamponi GW (2015) Role of prelimbic GABAergic circuits in sensory and emotional aspects of neuropathic pain. Cell Rep 12:752-759. CrossRef Medline

Zhou X, Qi XL, Douglas K, Palaninathan K, Kang HS, Buccafusco JJ, Blake DT, Constantinidis C (2011) Cholinergic modulation of working memory activity in primate prefrontal cortex. J Neurophysiol 106:2180-2188. CrossRef Medline 